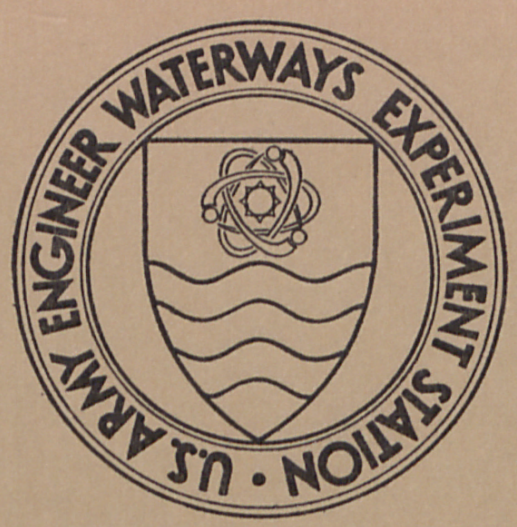

MISCELLANEOUS PAPER S-70-16

\title{
ORIGIN AND CHRONOLOGIC SIGNIFICANCE OF LATE QUATERNARY TERRACES OUACHITA RIVER, ARKANSAS AND LOUISIANA
} by

R. T. Saucier, A. R. Fleetwood

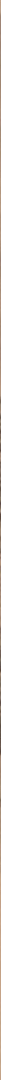

Prepared by U. S. Army Engineer Waterways Experiment Station, Vicksburg, Mississippi 


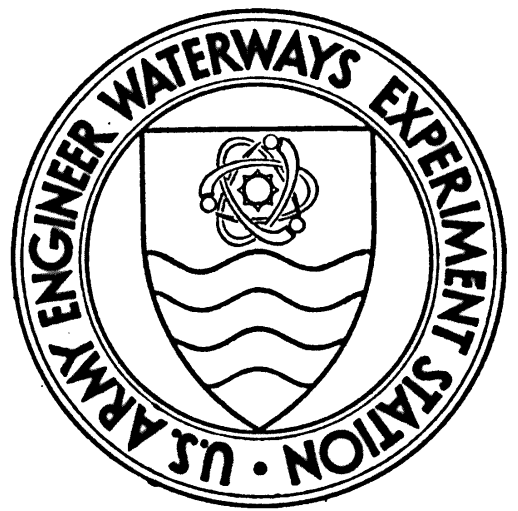

MISCELLANEOUS PAPER S-70-16

\section{ORIGIN AND CHRONOLOGIC SIGNIFICANCE OF LATE QUATERNARY TERRACES OUACHITA RIVER, ARKANSAS AND LOUISIANA by R. T. Saucier, A. R. Fleetwood}

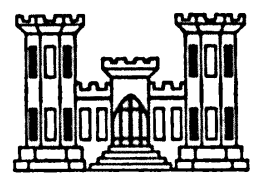

May 1970

Prepared by U. S. Army Engineer Waterways Experiment Station, Vicksburg, Mississippi 


\section{FOREWORD}

This paper was prepared by Dr. R. T. Saucier and Mr. A. R. Fleetwood of the Geology Branch, Soils Division, U. S. Army Engineer Waterways Experiment station (WES), for publication in the Bulletin of the Geological Society of America. Observations instrumental in the formulation of the concepts and conclusions presented in this paper were made during largescale engineering-geologic mapping programs conducted by the WES Geology Branch for the U. S. Army Engineer District, Vicksburg. The paper was reviewed and approved by the Office, Chief of Engineers.

Director of WES during preparation of this paper was COL Levi A. Brown. Technical Director was Mr. F. R. Brown. 
Abstract: Efforts to differentiate Quaternary alluvial deposits along the Ouachita River between Camden, Arkansas, and Monroe, Louisiana, according to environments of deposition have indicated the presence of five fluvial terraces, three of which are considered to comprise the Deweyville terrace sequence. This sequence, lying stratigraphically between the Prairie terrace and the Holocene floodplain, can be distinguished partly by large meander scars that are characteristic of the terrace where it is present on " several Coastal Plain streams. Previous investigations have established the age of the Deweyville terraces as being between 13,000 and 30,000 years before present; however, opinions vary regarding mode of origin. Morphologic characteristics of and stratigraphic relationships between the terraces along the Ouachita River indicate that a close causal relationship existed between the terraces and major episodes of aggradation and degradation in the Mississippi aliuvial valley, but changes in hydraulic regimen brought about by climatic change were also significant.

The chronological sequence indicated for the Ouachita Valley includes (a) deposition of the Prairie terrace formation during the Sangamon Interglacial Stage, (b) primary valley degradation and deep stream entrenchment during waxing Early Wisconsin glaciation, (c) alluviation during waning Early Wisconsin glaciation with maximum valley aggradation occurring during the Farmdalian Substage, (d) secondary valley degradation and moderate entrenchment during waxing Late Wisconsin glaciation, and (e) alluviation and valley aggradation during waning Late Wisconsin glaciation and continuing into the Holocene.

Rapid deposition of glacial outwash in the Mississippi Valley, including the development of an alluvial cone by the Arkansas River, resulted in the damming of the lower end of the Ouachita Valley during the Farmdalian 
Substage. A 500 to 700-sq-mile perennial lake, called Lake Monroe, was created by the damming: shoreline features and lacustrine plain remnants of the lake comprise what is recognized as the highest and intermediate Deweyville terraces. The lowest Deweyville terrace was created subsequently during a period of waxing glaciation and valley entrenchment and under the influence of a pluvial climate. Empirical equations suggest that stream discharges were 6 or 7 times greater than present and that precipitation was more than twice. that of present during this period. 
CONTENTS

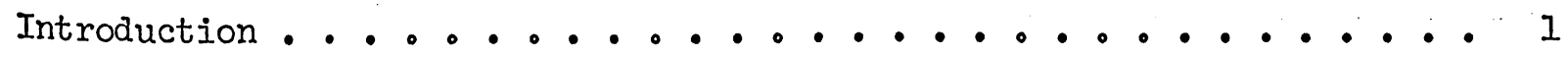

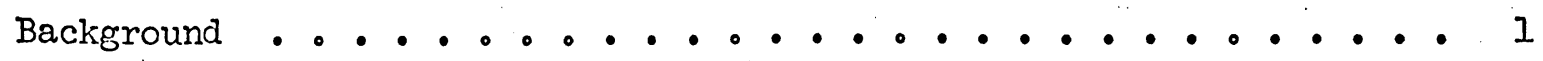

Scope . . . . . . . . . . . . . . . . . . . . . . 1

Methodology . . . . . . . . . . . . . . . . . . . 2

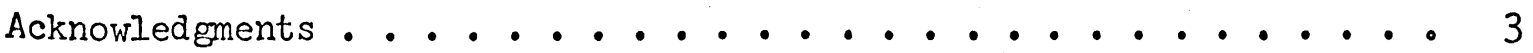

Geographic and Geologic Setting. . . . . . . . . . . . . . 3

General Stratigraphy and Nomenclature. . . . . . . . . . . . 6

Prairie and Montgomery Terraces . . . . . . . . . . . . 6

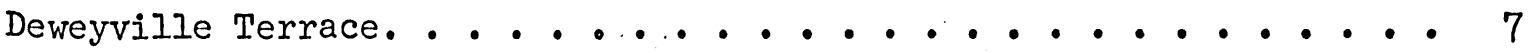

Terrace Morphology and Lithology . . . . . . . . . . . . 8

Introduction. . . . . . . . . . . . . . . . 8

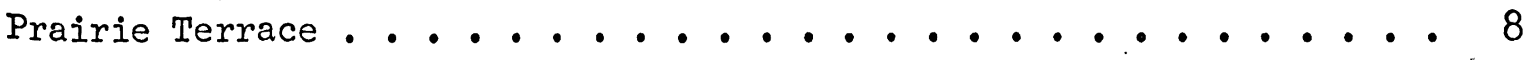

Deweyville Terraces 1 and 2 . . . . . . . . . . . . . 11

Deweyville Terrace 3. . . . . . . . . . . . . . . . 16

Holocene Floodplain. . . . . . . . . . . . . . . . . 18

Geologic History . . . . . . . . . . . . . . . . . . 21

Bạckground. • . . . • . . . . . . . . . . . . . . 21

Interpretation. . . . . . . . . . . . . . . . . . 23

Sangamon Interglacial Stage. . . . . . . . . . . . . 23

Early Wisconsin glaciation . . . . . . . . . . . . . 24

Farmalian Substage. . . . . . . . . . . . . . . . 26

Late Wisconsin glaciation. . . . . . . . . . . . . . 29

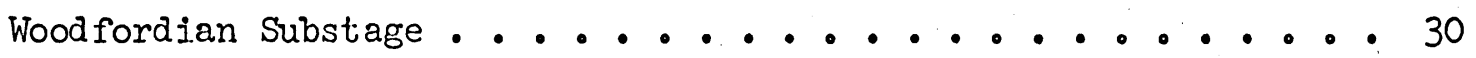

The Recent . . . . . . . . . . . . . . . . 32 
Discussion . . . . . . . . . . . . . . 33

Extinct Lakes . . . . . . . . . . . . . . 33 Age and Origin of Deweyville Terraces . . . . . . . . . . 35 Deweyville Paleoclimatology and Paleohydrology. . . . . . . 37 References Cited ........................ 46 
Figures:

1. Location of study area and relationship to the Lower Mississippi Valley. . . . . . . . . . . . . . . 5

2. Reconstmucted downvalley (Iongitudinal) terrace and floodplain profiles. . . . . . . . . . . . . . 10

3. Morphology of a typical lake beach or barrier and adjacent surfaces located about 7 miles southwest of Monroe, La.. . . . . 13 '

4. Extent and configuration of Lake Monroe and associated features . . 14

5. Lower Mississippi Valley chronological concepts (a) as proposed by

Fisk (1944), and (b) as applied by Saucier (1968) to sea level

fluctuation curve proposed by Curray (1965) . . . . . . 22

6. Diagrammatic illustrations of stages in the development of the

Ouachita Valley . . . . . . . . . . . . 25

7. Extent and configuration of the Farmdalian Substage Arkansas River cone (Macon Ridge) as related to the formation of Lake Monroe . . . २8

\section{Plates}

1. Quaternary geology, Ouachita River area, Arkansas and Louisiana . 50 2. A comparison of Deweyville and Holocene meander belt features . . . 51

Tables

1. Holocene and Deweyville (Qtd 3 stage) stream geometry measurements. 40

2. Holocene and Deweyville (Qtd 3 stage) stream discharges calculated from empirical equations. . . . . . . . . . . 43 


\section{INTRODUCTION}

Background

The general stratigraphy of Quaternary depositional terraces of both fluvial and marine origin in the central Gulf Coast area has been recognized for about 50 years. Nomenclature introduced by Fisk (1939) is most widely accepted as is his interpretation of the origin of the terraces in relation to waxing and waning glaciation and major sea level variations (Fisk, 1944). Alternate interpretations and nomenclature have been offered (Doering, 1956); however, the most serious objections raised have been: in relation to the ages of terraces and their correlation with specific Elacial or interglacial stages (Trowbridge, 1954; Leighton and Willman, 1949; Durham and others, 1967), particularly the older terraces. Since the work by Fisk, one of the few significant modifications to the Late Quaternary terrace stratigraphy has been the recognition by Bernard (1950) and the realization by Gagliano and Thom (1967) of the geographic extent and chronologic significance of the Deweyville terrace in the Gulf and Atlantic coastal plain areas. The mode of origin and relationship of this terrace to older terraces and to the Holocene floodplain of the -

Ouachita River are of major concern in this paper.

\section{Scope}

Delineation of the Quaternary formations along the Ouachita River was accomplished by Fleetwood during a three-year project conducted by the U. S. Army Engineer Waterways Experiment Station, Vicksburg, Miss., for the U. S. Army Engineer District, Vicksburg. The primary purpose of the project was to differentiate the Quaternary alluvial sequences according to 
environments of deposition and to assess the engineering properties of the sediments, both surficial and buried, in each environment. Detailed lithologic and stratigraphic data developed in the project are available in report form (Fleetwood, 1969) and are not presented in this paper.

The basic intent of the authors is to point out a causal relationship between the Quaternary terrace sequence of the Ouachita Valley and major episodes of aggradation and degradation in the Mississippi alluvial valley. Saucier (1968) has recently presented tentative evidence of a previously unrecognized Wisconsinan Stage cycle of valley cutting and filling in the Lower Mississippi Valley area and has offered a revised chronology: the Ouachita Valley terrace sequence can be satisfactorily explained only in terms of the new chronology and offers considerable additional substantiating evidence.

The secondary intent of this paper is to call attention to certain rather unusual geomorphic features that, in one case, indicate a period of well developed pluvial climate and, in another case, indicate an earlier period of widespread valley flooding and lake formation related to. Lower Mississippi Valley sedimentation patterns and rates.

\section{Methodology}

The extent of terrace mapping (Plate 1 ) is essentially coincident with the extent of available large-scale topographic mapping by the U. S. Army Corps of Engineers and the U. S. Geological Survey. Initial terrace identification and delineation was performed using contours while crossvalley and down-valley profiles, showing both actual and reconstructedsurface elevations, were used for modifications and refinements. Final 
delineations were achieved through an examination of the physiographic expressions of the terraces on aerial photographs and photo mosaics.

- Subsurface data. in the form of logs of wells and borings were used to establish terrace lithology and permitted estimates of such parameters as depths of river scour and valley entrenchment. Field reconnaissances of the study area proved to be generally unrewarding because of the low relief, heavy vegetation cover, lack of access to many large areas, and infrequent outcrops or road cuts.

In essence, this has been an intensive investigation of regional physiography. Geomorphological investigation techniques proved to be the most effective; and the geomorphic expression of landforms proved to be the most significant factor in discerning terrace stratigraphy and inferring modes of origin.

Acknowledgments

Special thanks are extended to Dr. Charles R. Kolb for his review of the manuscript and to both him and Mr. W. B. Steinriede, Jr., for their valuable critical discussions of the problem that helped crystallize our thinking. Mrs. Naomi J. Rhodman and Mrs. Mary E. Skipworth assisted with typing, and Mr. J. A. Sherlock provided editorial review. Supervision by -Mr. Nels J. Nyman of the extensive drafting assignment is appreciated. Approval by the Office, Chief of Engineers, of the manuscript for publication is acknowledged.

\section{GBOGRAPHIC AND GEOLOGIC SETTING}

The Ouachita River flows generally southeastward over an airline distance of about 300 miles from its headwaters in the Ouachita Mountains of 
west-central. Arkansas to where it becomes tributary to the Red River in east-central Iouisiana (Fig. I). It meanders freely and has created a 2to 5-mile-wide floodplain in the Coastal Plain between Malvern, Ark., and Sterlington, La. South of Sterlington, the river enters the Mississippi alluvial valley and flows as an underfit stream in an abandoned Holocene meander belt of the Arkansas River (Fig. I and Plate I).

The Quaternary valley of the Ouachita River is quite assymetrical between Camden, Ark., and Monroe, Ia. (Plate 1). Throughout most of this distance, the present river is at the base or within 5 to 10 miles of the western valley wall which rises abruptly to heights of 100 to 150 ft above the floodplain. Upland formations west of the river are of Eocene age (Claiborne Group) and are composed of thinly-bedded and mostly unindurated. clays, silts, and fine sands of shallow marine or deltaic origin. East of the present river, one must cross a 20 - to 25 -mile-wide, step-like sequence of low, flat terraces before encountering pre-Quaternary formations at similar elevations.

The Eocene formations strike roughly northeast-southwest, dip gently to the southeast, and have been only moderately affected structurally。 At least one major fault zone crosses the Ouachita Valley near Smackover, Ark.; however, an almost complete absence of evidence of faulting in quaternary deposits indicates general quiescence since Tertiary times. Differential erosion of the Eocene formations has resulted in a maturely dissected- upland landscape with faint suggestions of cuestas.

The Ouachita River floodplain north of Sterlington is subject to annual flooding and consequently is uninhabited and heavily timbered with deciduous hardwoods. "Numerous shoals and bars characterized the river at 


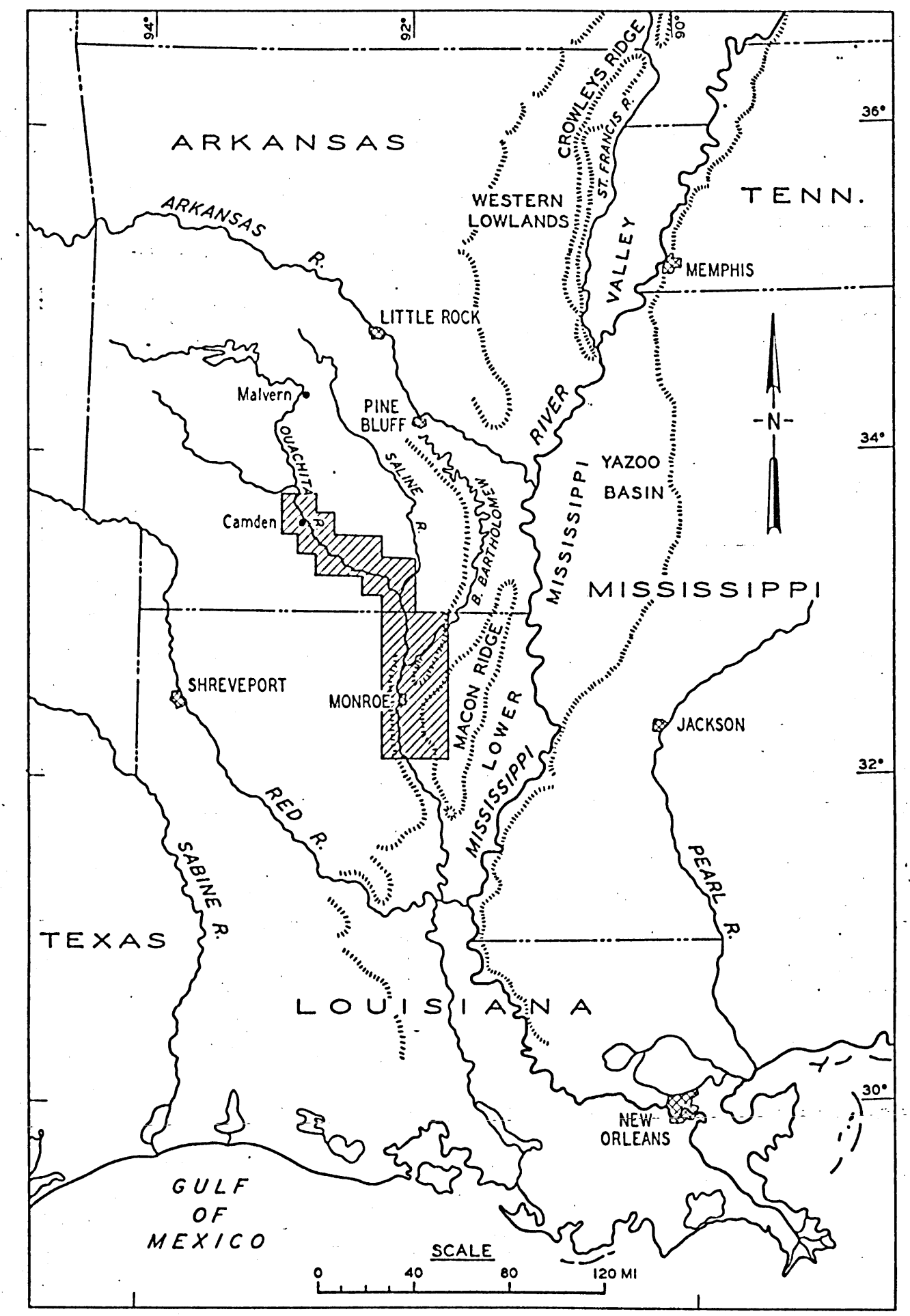

Figure 1. Location of study area and relationship to the Lower Mississippi Valley.

5 
low water in its natural state, but a series of small locks and dams now provides a navigable channel to Camden. The terraces are sparsely populated; widespread pine forests support an extensive lumbering industry. South of Sterlington, the higher and wider natural levees of the old.Arkansas River courses are extensively cultivated and industrialized and well-populated, with Monroe being the largest urban complex.

\section{GENERAI STRATIGRAPHY AND NOMEINCLATURE}

Prairie and Montgomery Terraces

The Prairie terrace formation (Fisk, 1939) is the most areally extensive Quaternary terrace in the Ouachita River area (Plate I) and also the most easily identified terrace in regard to surface morphology and relative topographic position. Although the Prairie terrace was originally assigned by Fisk to the Peorian (Bradyan) Interglacial Stage, several recent investigations in the Gulf and Atlantic-Coastal Plain areas have indicated evidence for the assignment of the Prairie or its equivalents (Beaumont of Texas and Pamlico of Florida and Georgia) to the Sangamon Interglacial Stage (Gagliano and Thom, 1967; Hoyt and others, 1968; Schnable, 1966). Evidence for such an assignment is present in the Lower Mississippi Valley (Saucier, 1968) and also in the Ouachita valley.

Maturely dissected remnants of à terrace situated topographically higher than the Prairie occur in the extreme northeast part of the mapped area. Little attention has been devoted to this terrace; however, superficially it appears to meet the criteria set forth by Fisk (1939) for the Montgomery terrace. 
Deweyville Terrace

The name Deweyville was first applied by Bernard (1950) to a low depositional terrace along the lower Sabine River in Texas and Louisiana. Recognition of the Deweyville as a distinct terrace formation was based on its intermediate position between the Prairie terrace and the Holocene floodplain and the presence of distinctive meander scars several times larger in width and radii than those of the present river. Bernard considered a pluvial climate explanation for the large meander features but concluded that they were more likely attributable to a rapid rise in sea level in Late Wisconsin times.

In this initial work on the Deweyville, Bernard recognized similar. terraces along the Brazos, Trinity, and Pearl Rivers of the central Gulf Coast area and was aware of a possibly related terrace along the Ouachita River. Somewhat later, Bernard and IeBlanc (1965) expressed an opinion, as have Gagliano and Thom (1967) and Saucier (1968), that the Deweyville terrace probably correlates with braided streamsurfaces in the Mississippi alluvial valley. Published (Pearson and obhers, 1966, p. 458) and unpublished radiocarbon dates from along several Gulf Coast rivers suggest formation of the Deweyville terrace between about 13,000 and 30,000 years before present.

As many as three levels or sub-terraces have been recognized (Gagliano and Thom, 1967; Gagliano, personal communication) along the Sabine and Trinity Rivers where large-scale topographic mapping is available and has been examined in detail. Along the Ouachita River, three terrace levels occur between the Prairie terrace and the Holocene floodplain. Although 
only the lowest level, designated as the Qtd 3 level. (Plate 1), exhibits large meander scars, all three levels are considered to comprise the Deweyville terrace. Evidence considered more conclusive than has heretofore been available will be presented later in this paper to demonstrate a close relationship of all three terrace levels to the Mississippi alluvial valley braided surfaces and to further substantiate the suggested time span.

\section{TERRACE MORPHOIOGY AND IITHOLOGY}

Introduction

Each Quaternary terrace formation, including the Holocene alluvium, is a depositional sequence consisting of a fine-grained topstratum (clays and silts) and a coarse-grained substratum (sands and gravels). The topstratum-substratum thickness ratio of about 1:2 or 1:3 remains rather uniform throughout the area except on the older terraces where portions of the topstratum have been removed by erosion. Topstratum deposits primarily represent overbank deposition in natural levee, backswamp (flood-basin), and abandoned channel or course environments, whereas substratum deposits were laid down in point bar, channel lag, and possibly braided-channel bar environments (Allen, 1965; Fleetwood, 1969). The only significant exception to this occurs in relation to the downstream portions of the $\mathrm{Qtd}_{1}$ and atd 2 terraces where much of the topstratum represents deposition in a lacustrineenvironment.

\section{Prairie Terrace}

Interfluve areas of the Prairie terrace formation are sufficiently well preserved to permit reconstmuction of former elevations and slopes, 
although differential erosion has reduced the once nearly flat relict floodplain to a gently rolling to moderately hilly landscape. As indicated in Figure 2, the formation exhibits a reconstructed domvalley slope that waxes southward from about $0.33 \mathrm{ft} / \mathrm{mile}$ above Felsenthal, Ark., to over $0.75 \mathrm{ft} / \mathrm{mile}$ below Monroe. The convex slope profile is quite similar to that of the present river at natural low water; the two remain separated by about $110 \mathrm{ft}$ over a distance of about 90 miles.

Subsurface data indicate that the Prairie terrace formation was deposited on an erosional surface on Claiborne Group deposits that was almost certainly formed as a result of entrenchment during a preceding glacial stage, probably the Illinoian. Iocal relief on the erosion surface appears to be less than $40 \mathrm{ft}$. In view of a lack of any indications of soil profile development or subaerial weathering characteristics, it is assumed that erosion took place beneath an alluvial cover as a result of lateral and vertical stream corrasion.

Possible differentiation of the Prairie terrace formation according to parent stream is suggested by a distinct variation in the thickness of the terrace formation. All of the formation in Arkansas and that portion located west of the Ouachita River in Iouisiana (Plate I) has a thickness varying from about 60 to 75 ft and was undoubtedly deposited by an . ancestral Ouachita River. The portion of the terrace formation situated east of the river in Iouisiana, which includes the Bastrop Hills, has an average thickness of about $140 \mathrm{ft}$, suggesting deposition by the larger ancestral Mississippi River.

Even where essentially undissected, the Prairie terrace formation has 


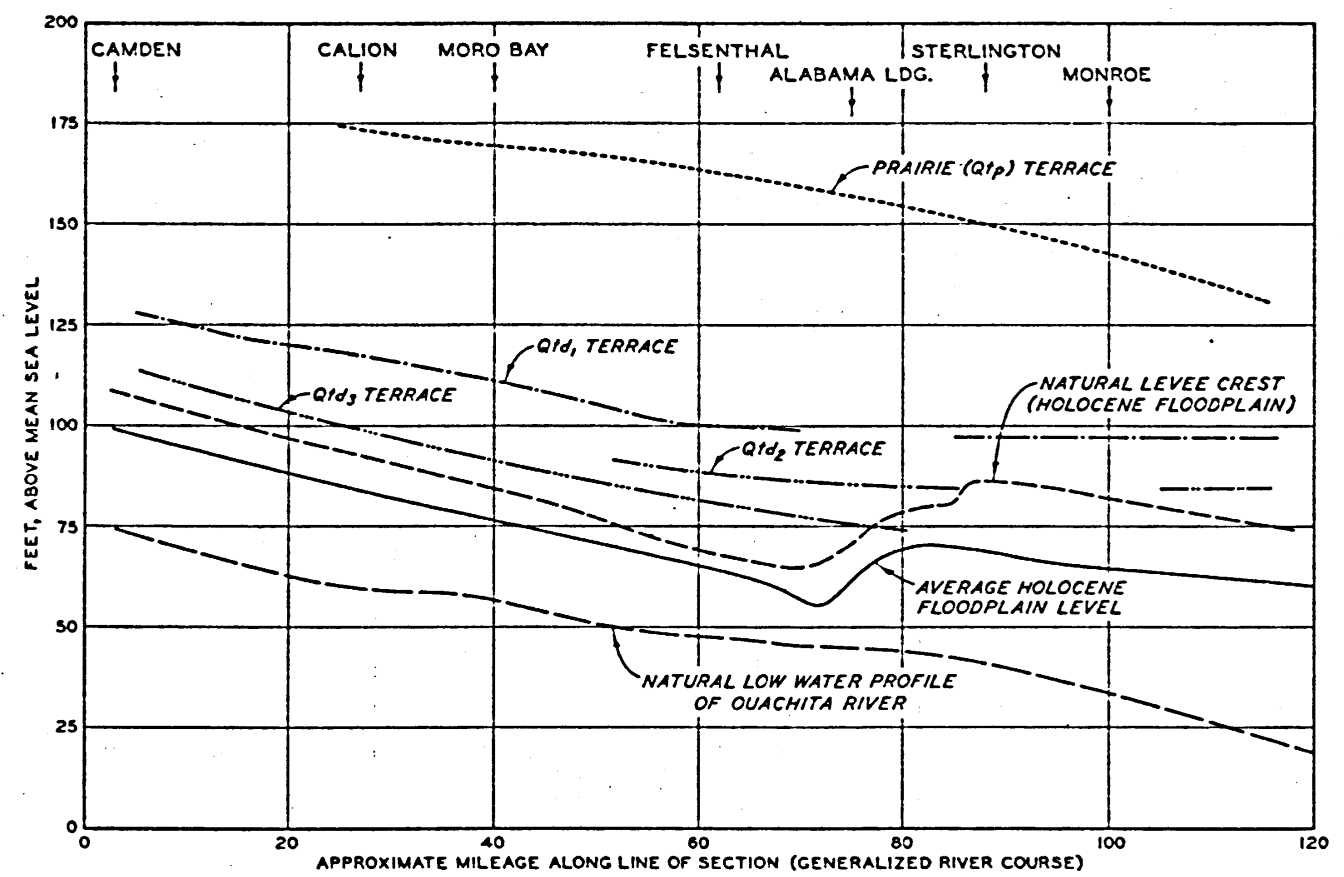

Figure 2. Reconstructed downvalley (Iongitudinal) terrace and floodplain profiles. 
a completely amorphous surface expression. Relict channel scars are totally lacking; hence, no indication of former stream patterns or dimensions can be obtained.

\section{Deweyville Terraces 1 and 2}

The highest Deweyville terrace formation, the Qtd 1 terrace, is widespread north of the Ouachita River in Arkansas and occurs at scattered localities on both sides of the river in Louisiana. It is only slightly dissected as compared with the Prairie terrace formation. Where large continguous areas exist, such as along Moro Creek and in the Flatwoods terrace area (Plate 1), interfluves exhibit relief of less than 5 ft over areas of severai square miles. The intermediate Deweyville terrace formation, designated as the Qtd 2 terrace, occurs along the lower Saline River in Arkansas and along the Ouachita River essentially onily south of the Saline River. Surface relief on this terrace is comparable to that on the Qtd ${ }_{1}$ terrace. Upstream from Felsenthal, the Qtd 1 terrace has a rather uniform downvalley slope of about $0.50 \mathrm{ft} / \mathrm{mile}$ (Fig. 2). However, near.Felsenthal the slope abmuptly declines to less than $0.1 \mathrm{ft} / \mathrm{mile}$, and south of Alabama Landing, the surface slope is zero. The Qtd 2 terrace exhibits a similar decline in downvalley slope and it also finally attains a zero slope south of Monroe.

This decline in slope was an enigma to the authors for an appreciable period during the study, particularly when considered in comparison with the slopes of the other terraces and the Holocene floodplain. The only possibly tenable explanation for this was that the Ouachita River during this time was shallowing its gradient and aggrading its floodplain in response to rapid alluviation in the Mississippi alluvial valley. 
Considerable evidence has subsequentiy been discerned that supports this hypothesis, by far the most significant evidence being in the form of a series of low ridges such as the one illustrated in Figure 3. These. ridges, delineated in red in Plate 1 , occur on both sides of the Ouachita River south of the Arkansas-Iouisiana state line. Regardless of length or location, they all have a relatively constant width of 1000 to $2000 \mathrm{ft}$, they have conspicuously accordant crest elevations varying only from about 103 to $105 \mathrm{ft} \mathrm{msl}$, they stand at least $10 \mathrm{ft}$ and usually $20 \mathrm{ft}$. above the adjacent terrace levels, they always occur on the $Q t d_{I}$ terrace at its contact with the Qtd 2 terrace, and, with but one exception, drainage is developed immediately adjacent and parallel to the ridges on the higher terrace side. Profiles normal to the ridges all show relative elevation differences and slopes similar to those. included in Figure 3.

It has been concluded that these features are beach ridges that formed around a large possibly seasonal but more likely perennial lake for which... the authors introduce the name Iake Monroe. - The probable extent of the lake. is indicated in Figure 4.

The exceptional flatness, both local and regional, of the main extent of the Qtd 1 terrace below the state line and its position relative to the beach ridges suggest that it was a backbeach or backbarrier flat that was subject to inundation only during extremely high lake stages. The Qtda terrace is interpreted as being the relict lake bottom or lacustrine plain. Saline River is considered to mark the approximate northernmost extent. of the lake; the sloping atd ${ }_{I}$ terrace north of this point along the Ouachita is the relict floodplain of the ancestral river before it discharged into the lake. Meander scars and occasional abandoned channels similar in size 

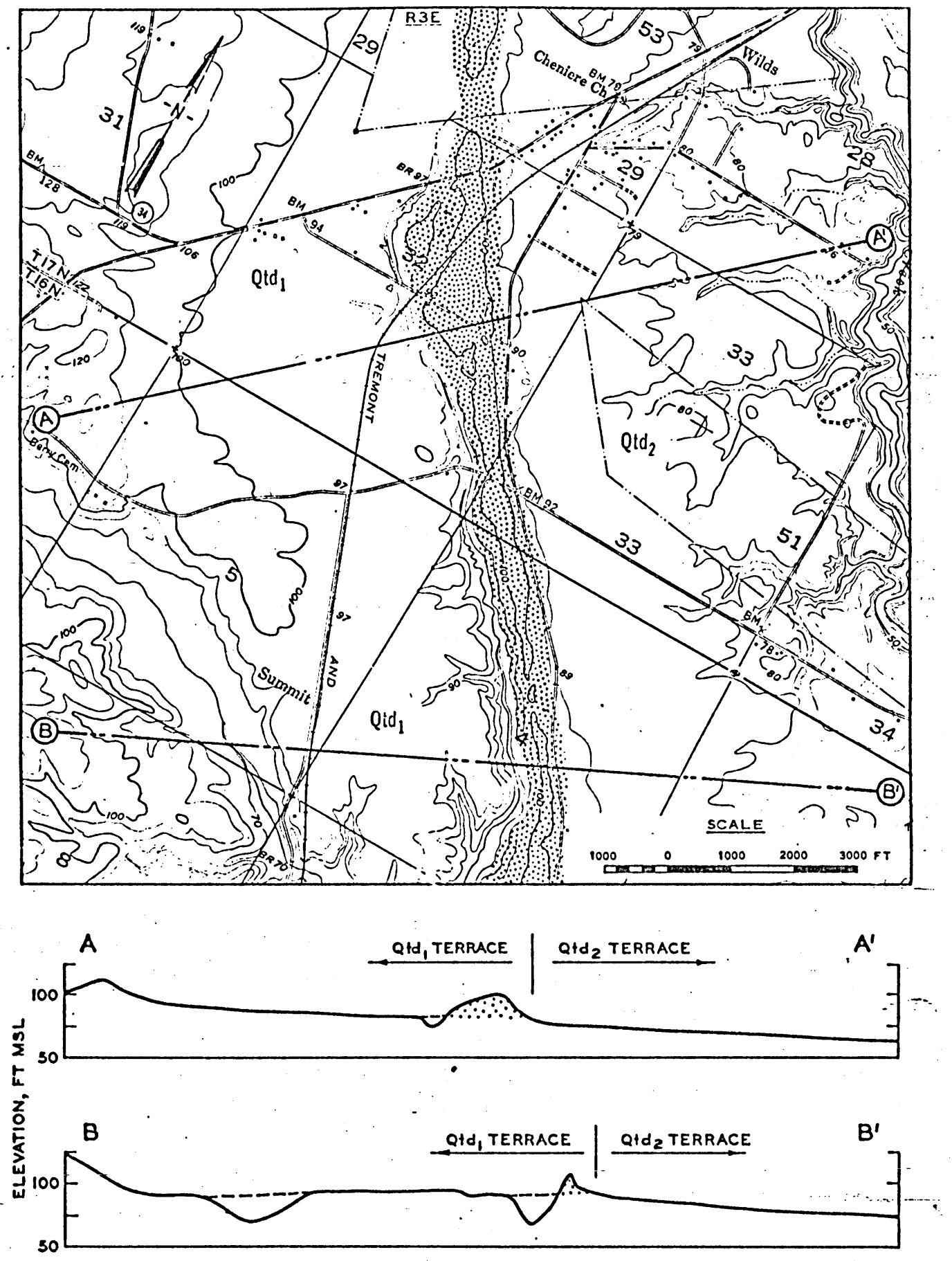

Figure 3. Morphology of a typical lake beach or barrier and adjacent surfaces located about 7 miles southwest of Monroe; Ia: 


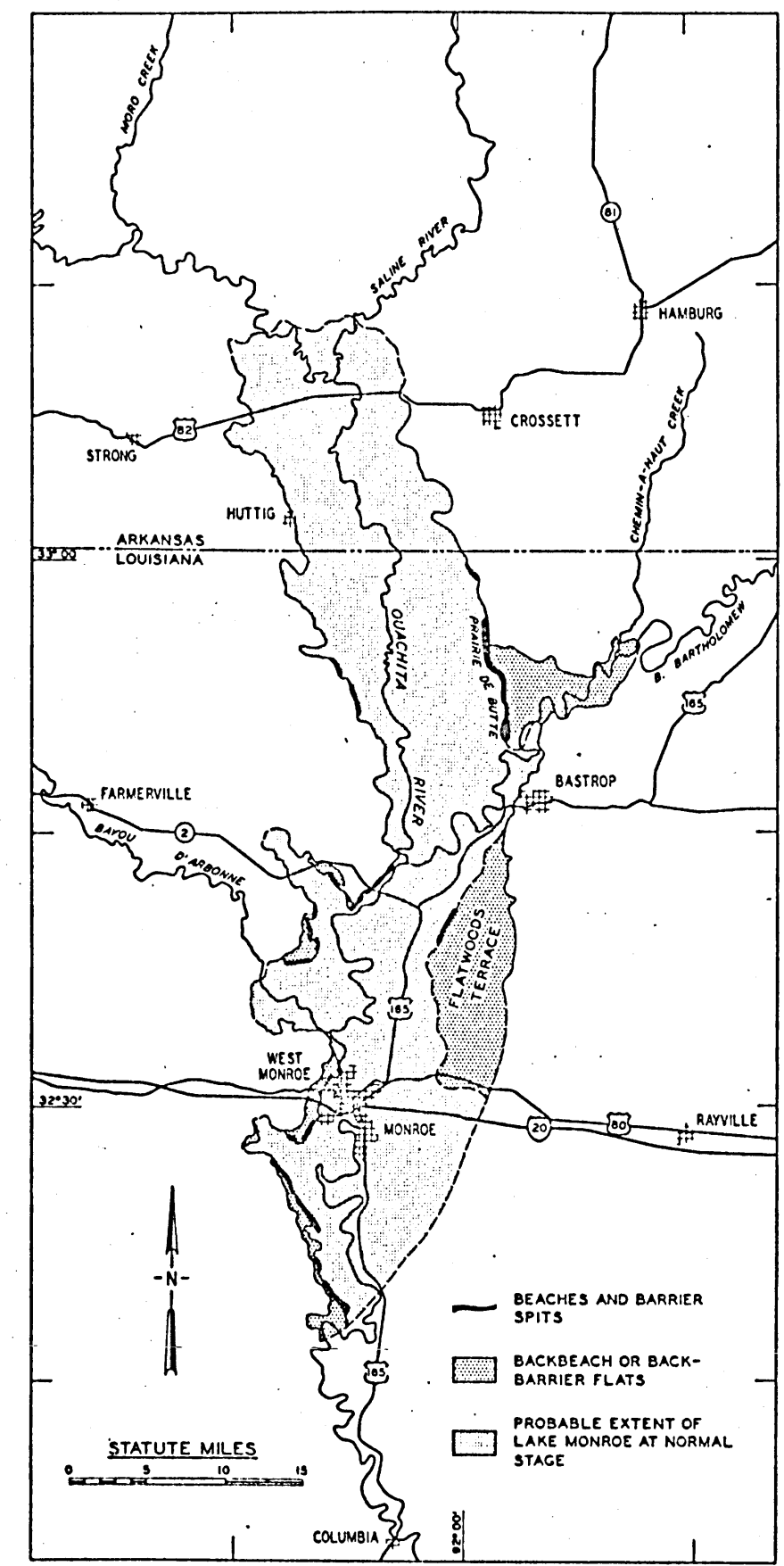

Figure 4. Extent and configuration of $\therefore$ Lake Monroe and associated features. 
to those of the present river are discernible on this terrace in the Moro Bay area, while the backbeach or backbarrier flat portions of the terrace have a completely amorphous surface expression.

At normal stage, extinct Iake Monroe is estimated to have had an area of about $500 \mathrm{sq}$ miles (Fig. 4) and a mean maximum depth of 20 to $25 \mathrm{ft}$. The area of the lake may have been as much as $700 \mathrm{sq}$ miles at extremely high stages; however, the depth would have been only 5 to $10 \mathrm{ft}$ greater. These area determinations are based on the assumption that the lake did not extend appreciably beyond a line drawn connecting the southernmost extent of the Qtd $_{1}$ terrace on the east and west sides of the Ouachita River (Plate I). The lithology of the Qtd $_{1}$ and Qtd 2 terraces varies little from the characteristic fine-grained topstratum/coarse-grained substratum sequence previously mentioned. The fact that the sequence is present to the southernmost extent of the terraces, including the area occupied by Lake Monroe, indicates a fluvial origin for most of the terrace sediments in that area. Probable lacustrine and backbeach-flat sediments apparently overlie the fluvial sequence as a thin veneer and have been observed at only two locations: in the Flatwoods Terrace area, where the atd 1 terrace topstratum is unusually thick and contains large quantities of silt-size material, and in an area about 6 miles southwest of Monroe, where the same terrace exhibits extensive deposits of fine sands and silts in the topstratum. Samples from these two areas were analyzed, but no sedimentologic or paleontologic evidence was discerned that confirmed deposition in a lacustrine or lacustrinerelated environment.

The Qtd $_{2}$ terrace is erosional rather than depositional in at least one area southwest of Monroe. All terrace morphologic criteria are 
satisfied; however, outcropping sediments are the ironstone-bearing, finelybedded clays and silts of the Cockfield formation of the Claiborne Group (Fleetwood, 1969). It is assumed that this occurrence is attributable to subaqueous planation by nearshore currents in Lake Monroe。

Judging from a few scattered road cuts, aggregate pits, and borings, the beach ridges appear to be composed primarily of irregularly stratified sands and gravels undoubtedly reworked from nearby fluvial terrace deposits。 The only observed exception to this is the 8-mile-long, north-south trending ridge called Prairie de Butte located north of Bastrop, La. (Plate I). A 12-ft-high exposure in a canal bank cutting through a portion of this ridge shows only massive to faintly-stratified, well-sorted fine sands. The lithology, morphology, and location of Prairie de Butte suggest it was a barrier spit that partially enclosed, an arm of Lake Monroe extending up the floodplain of Chemin-a-Haut Creek. Bayou Bartholomew in this area is a fairly recent occurrence not related to the lake.

Deweyvilie Terrace 3

The lowest of the Deweyville terraces is intermittently present on both sides of the river from at least 12 miles north of Camden downstream to 12 miles south of the Arkansas-Iouisiana state line (Plate 1). The downvalley slope profile (Fig. 3) is slightly concave, the slope decreasing from about $0.60 \mathrm{ft} / \mathrm{mile}$ above Camden to about $0.30 \mathrm{ft} / \mathrm{mile}$ just north of the downstream-most point. South of this point, the Qtd 3 terrace formation undoubtedly is present at least intermittently in the subsurface, being buried by the Holocene natural levees along abandoned Arkansas River courses such as the Bayou Bartholomey course.

Dissection of the $\mathrm{Qtd}_{3}$ terrace is comparable in magnitude to that of 
the Qtd $_{1}$ terrace in Arkansas; however, there is one major difference. Drainage patterns on the Qtd 1 terrace now reflect little or nothing of the control or influence once exerted by primary depositional features of the former floodplain, whereas on the $\mathrm{atd}_{3}$ terrace, the control of the relict features is strikingly evident.

Relict features present on the $\mathrm{Qtd}_{3}$ terrace include numerous abandoned channels, segments of abandoned courses, and extensive areas of point bar ridge and swale topography (meander scrolls). These features are the most outstanding and diagnostic characteristics of the terrace and are present throughout the mapped extent of the terrace.

Two abandoned channels and related point bar topography. on the $\mathrm{atd}_{3}$ terrace between Calion, Ark., and Moro Bay are visible on the photomosaic in Plate 2. These features illustrate well the significant size differences between the Deweyville-stage stream and the present stream that are so typical not only along the Ouachita but along most Gulf Coast rivers. Measurements in this area indicate that the $\mathrm{atd}_{3}$ terrace channels are approximately 3 times wider than the present stream channel and that the meander'radii and meander wavelengths are probably about 2 times greater than those of the present stream. These average size differences are not so great as they are along certain other Gulf Coast streams; however, . they still would fall within estimated ranges (Gagliano and Thom, 1967). On the basis of sparse and poor quality data, it appears that the Qtd 3 terrace formation substratum is proportionately thicker than is the.. case in the other Deweyville formations and that the complete fluvial sequence might be somewhat thicker than in the other formations... These 
differences are not surprising considering the larger stream channels and the inferred greater discharges and thalweg depths associated with the Qtd 3 terrace.

The lithology of the $\mathrm{Qtd}_{3}$ terrace formation topstratum and substratum. is not know to differ from that of the other terrace formations in any respect. No reliable data are available to indicate the nature of the deposits filling the large abandoned channels and courses; it can only be assumed that they are filled primarily with fine-grained sediments (clays and silts) as are the Holocene channels and courses of the Ouachita and Mississippi Valleys.

\section{HOLOCENE FIOODPIAIN}

The only portion of the Holocene floodplain of the Ouachita River that can be considered typical of that stream is the part extending downstream to about the mouth of the Saline River. Below this point, the stream has been profoundly influenced directly or indirectly by the Arkansas River. This influence is manifested in the slope, width, morphology, and lithology of the Holocene alluvial sequence.

The downvalley slope of the floodplain above the Saline River (section mile 56, Fig. 2) is uniform at a rate of about $0.55 \mathrm{ft} / \mathrm{mile}$. Flood-plain limits are easily defined by a low scarp or other physiographic expression, and the floodplain consists of the present meander beit and short segments of usually not more than one abandoned meander belt. All meander belt segments exhibit numerous abandoned channels or cutoffs. Floodplain relief, i.e. the difference between natural levee crests and abandoned channels or point bar swales, is generally not more than $15 \mathrm{ft}$. South of Sterlington, the Ouachita River is an underfit stream 
flowing in an abandoned Arkansas River meander belt. The profiles along the Holocene floodplain (average level) and natural levee crests in Figure 2 illustrate well the differences in elevation and slope that are present below Sterlington. Before the development of the Bayou Bartholomew course of the Arkansas River, the Ouachita River floodplain is assumed to have continued to slope downstream below Sterlington at about the same rate as it now does above the mouth of the Saline River. However, the major change illustrated in Figure 2 resulted when the Arkansas River aggraded to a level sufficiently high to permit it to divert through a narrow gap in the Prairie terrace formation at the north end of the Bastrop Hills (Plate I) into the Chemin-a-Haut Creek floodplain thence into the Ouachita floodplain. The Arkansas River initially achieved a major steepening of gradient through this diversion but rapidly adjusted by quickly building up the floodplain to heights of 20 to $30 \mathrm{ft}$ above its former elevation.

The relatively large natural levees along the Arkansas River course, as compared with the Ouachita River levees, are but one expression of the substantially higher sediment load (particularly silt-size material) of the former stream. Because of the Arkansas River's appreciably greater alluviation capacity, an extensive alluvial cone was built by the river upstream into the Ouachita Valley north of Sterlington from the Bayou Bartholomew course. The effect of the development of the cone and the corresponding shallowing of the gradient of the Ouachita River (Fig. 2) has been one of alluvial drowning and is manifested by the large, frequently-inundated, swampy lowland or flood basin called Grand Marais (Plate 1) which is located immediately upstream from the cone between 
Felsenthal and Alabama Landing, La. Within the flood basin, the Ouachita River natural levees are poorly developed, the floodplain relief is minimal, and the river has abandoned meander belts more frequently than anywhere else. In sharp contrast to this, the Ouachita River exhibits characteristics of an entrenched stream such as a less sinuous channel, few abandoned channels or cutoffs, and a narrow floodplain with no abandoned meander belts where it flows through the cone south of Alabama Landing (section miles 70 to 85 , Fig. 2).

Investigations conducted near the turn of the century first called attention to the anomalous behavior of the Ouachita River between Felsenthal and Sterlington (Veatch, 1906). Faulting was postulated as the cause of the Grand Marais; however, neither physiographic nor subsurface evidence has ever been discerned to substantiate this. Moreover, the downvalley terrace profiles constructed for this study (Fig. 2), indicating no vertical displacements, are considered as conclusive evidence that none of the Quaternary formations in this area have been significantly affected by faulting.

Local variations in the thickness of the Holocene topstratum are appreciable; however, it is possible to detect a downstream increase in average thickness from about $20 \mathrm{ft}$ above Calion to about $50 \mathrm{ft}$ below Monroe. As would be expected, a major change in the character of the topstratum occurs in the vicinity of Sterlington. Upstream from this point, the Holocene topstratum is composed essentially of sediments deposited in natural levee, abandoned channel, and abandoned course environments. Sediments deposited in a backswamp or floodbasin environment are volumetrically insignificant and have not been delineated (Fleetwood, 1969). 
Downstream from Sterlington, backswamp deposits comprise 75 percent or more of the topstratum: natural levee deposits and abandoned channel and course deposits are confined to the narrow and widely separated meander belts.

The Holocene substratum deposits generally cannot be precisely delineated either upstream or downstream from Sterlington. In many cases the Holocene sequence is apparently thinner than the atd 3 terrace formation sequence; consequently, Holocene sands and gravels are underlain as well as flanked by Qtd 3 terrace formation sands and gravels. Only in those cases where the Holocene sequence overlies Claiborne Group deposits off the flank of the Qtd $_{3}$ floodplain can the substratum sequence be defined. A substratum thickness of 20 to $40 \mathrm{ft}$ is typical of these locations.

\section{GEOIOGIC HISTORY}

Background

The most widely accepted and almost traditional correlation of Wisconsinan stage events in the Lower Mississippi Valley area with waxing and waning glaciation and corresponding eustatic sea level variations was first proposed by Fisk (1944) and has been modified little since that time. As indicated in Figure 5a, entrenchment of the Mississippi alluvial valley (and tributaries) is correlated with waxing Late Wisconsin glaciation and a falling sea level. Filling of the entrenched valley, first by braided streams choked with coarse-grained glacial outwash then by meandering streams carrying a smaller and finer load, is correlated with waning glaciation and a rising and finally a static sea level.

In 1968, Saucier presented evidence which indicated that. some of the fans or cones in the Mississippi Valley built by braided streams are 
YEARS BEFORE PRESENT

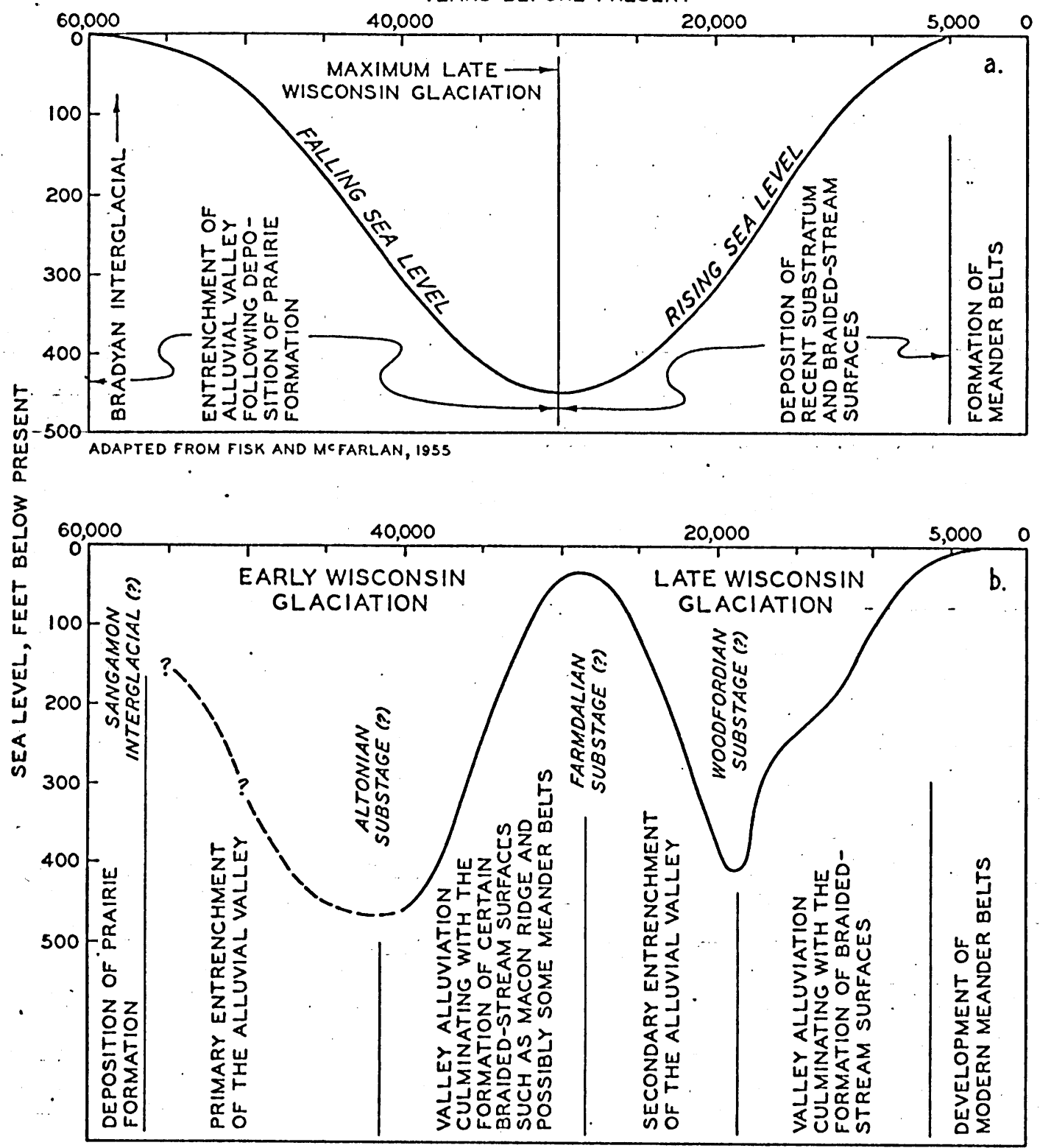

ADAPTED FROM SAUCIER, 1968

Figure 5. Lower Mississippi Valley chronological concepts (a) as proposed by Fisk (1944), and (b) as applied by Saucier (1968) to sea level fluctuation curve proposed by Curray (1965). 
appreciably older than had been thought and must be related to a preceding period of waning glaciation. A concept of Late Quaternary chronology developed by Curray (1956) based on evidence from continental shelf areas appeared to offer the only satisfactory explanation for the two phases of braided-stream deposition and two phases of valley entrenchment observed by Saucier (1968) to have occurred following deposition of the Prairie terrace formation. The correlation of alluvial valley events with Curray's sea level curve and chronology is indicated in Figure $5 \mathrm{~b}$.

Varying interpretations could be offered for many individual aspects of the Ouachita Valley terrace sequence if considered separately. However, the total sequence or aggregate situation indicates basic agreement only with the chronology indicated in Figure 5b. The following paragraphs contain the authors' interpretations of the origin of the Ouachita valley terraces based on this chronology.

Interpretation

Sangamon Interglacial Stage. Everywhere in the Gulf Coast area, the Prairie terrace formation (or equivalent) displays evidence of having been formed during a relatively long interglacial stage with a stable climate and little or no variation in sea level. The coastwise plain portion of the formation has conspicuous and well preserved beach, lagoon, and barrier island features. The riverine plain or relict floodplain portions of the formations on all Gulf coast streams, including the Ouachita River, indicate attainment of a rather advanced state of maturity, with low floodplain relief and a thick topstratum formed by rather slow accumulation of sediments through overbank deposition. In the Ouachita valley, paleochannel evidence is lacking, and it can only be assumed that the stream at 
this time (i.e. the Sangamon Interglacial Stage) was similar in size and character to the present river. Figure 6a diagrammatically illustrates probable conditions in the Ouachita River area during this stage.

Early Wisconsin glaciation. With the onset of the Early Wisconsin glaciation, the ancestral Ouachita River began to degrade its valley and become entrenched. This was probably in part a direct response to a lowering of the river's local base level (i.e. the Mississippi River) because of adjustment to a falling sea level and in part a result of a climatically-induced change in river regime.

The degradational stage probably persisted until or shortly beyond the maximum extent of the Early Wisconsin glaciation or the Altonian Substage (Fig. 5b), a period of possibly 15,000 years or more. During this time, much but probably not all of the Prairie terrace formation was removed by erosion. It is logical to assume that at least isolated areas of substratum remained. In those areas where the Prairie formation was probably completely removed and erosion affected the underlying Claiborne Group deposits, the erosional contact shows no evidence of subaerial weathering. This suggests that the basic mechanism of erosion or entrenchment may have been scouring or corrasion by shifting and seasonallyenlarging stream channels.

Figure $6 \mathrm{~b}$ illustrates the probable conditions existing in the Ouachita Valley immediately following the Altonian Substage during the early stages of the retreat or waning of the Early Wisconsin Glaciation.- Although the Ouachita River carried no glacial outwash, early deposition consisted almost entirely of sands and gravels, implying braided-stream deposition. Sediments deposited later are noticeably finer grained and undoubtedly 


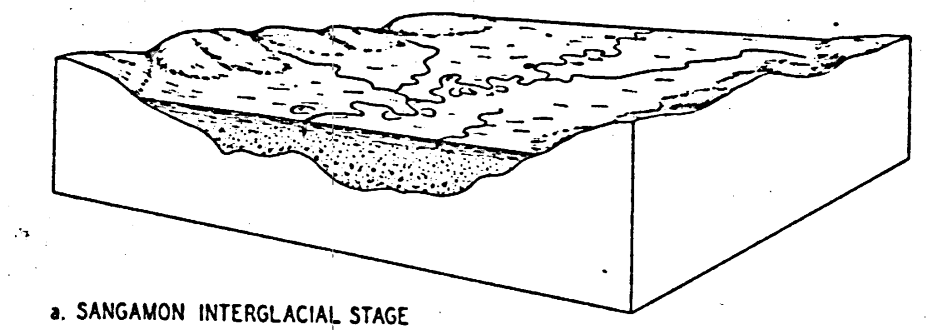

a. SANGAMON INTERGLACIAL STAGE
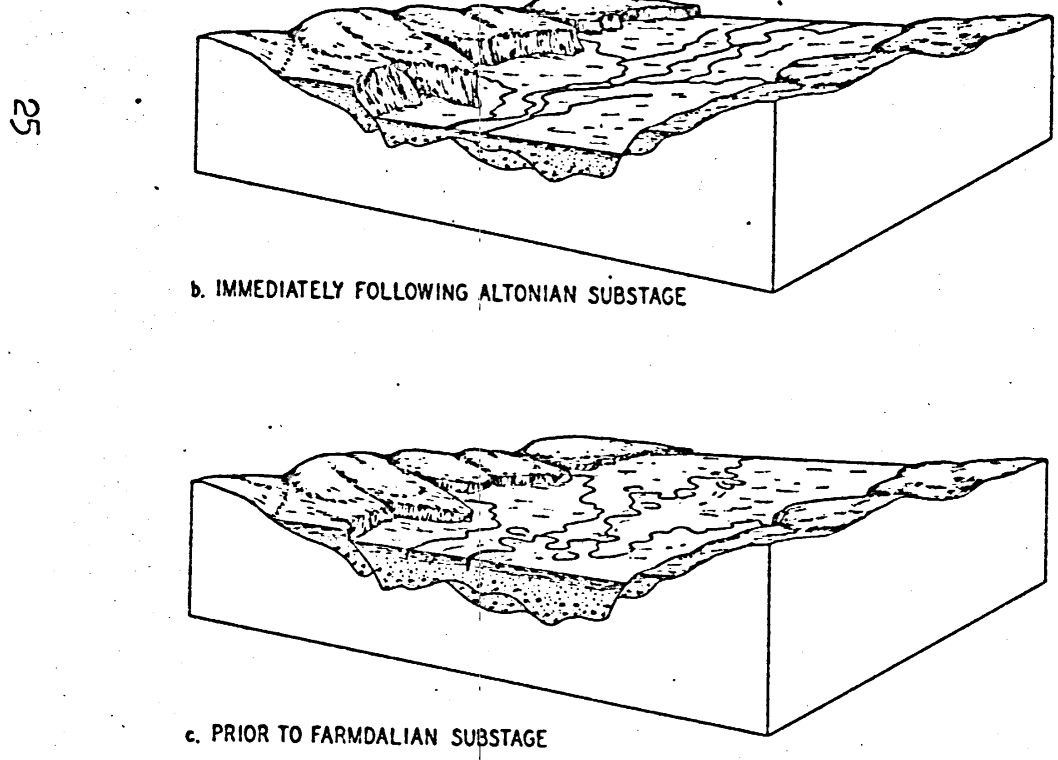

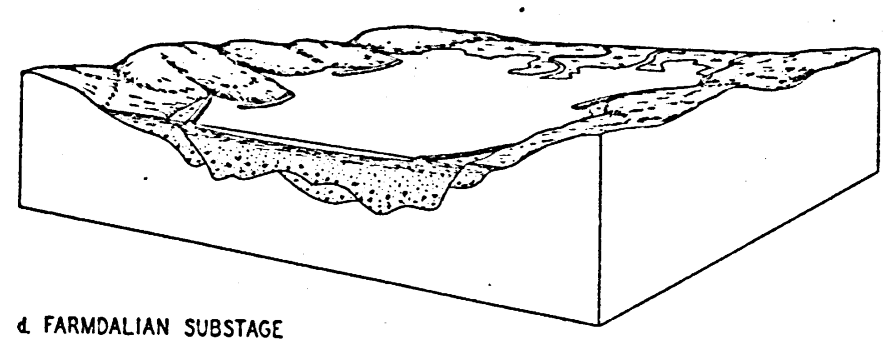

d. FARMDALIAN SUBSTAGE

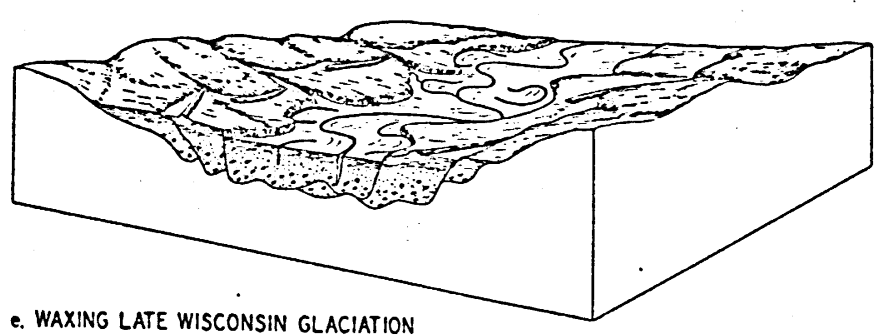

e. WAXING LATE WISCONSIN GLACIATION

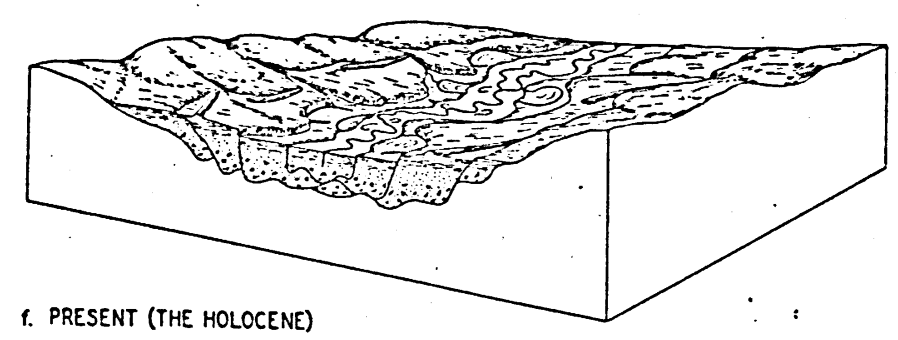

Figure 6. Diagrammatic illustrations of stages in the development of the Ouachita Valley. 
reflect a change from a braided to a meandering regime. Assuming the time scale.shown in Figure $5 \mathrm{~b}$ to be correct, the period of alluviation following the Altonian Substage lasted for about 10,000 years. Probable conditions in the Ouachita Valley near the end of this period of alluviation and prior to the Farmdalian Substage are illustrated in Figure 6c.

Farmdalian Substage. It is necessary to consider the post-Altonian Substage events in the Mississippi alluvial valley to interpret conditions in the Ouachita River area during the Farmdalian Substage (Fig. 5b). Throughout the period of waning Early Wisconsin glaciation, the ancestral Mississippi and Ohio Rivers carried copious quantities of glacial outwash and rapidly aggraded the valley through deposition of coarse-grained alluvium. The axis of the Mississippi River valley train is indicated by drainage patterns as being west of and parallel to Crowleys Ridge in the Western Iowlands (Fig. I) thence across the present Mississippi River course into and parallel to the eastern side of the Yazoo Basin. The Ohio River valley train apparently developed east of Crowleys Ridge and merged . with the Mississippi River valley train in the upper part of the Yazoo Basin. During this time, the Arkansas River apparently had a significantly greater discharge because of greater precipitation in its drainage basin and/or meltwater from Cordilleran glaciers. Below Little Rock, Ark。, the river was a braided stream carrying large quantities of sands and gravels. and it developed a long, narrow alluvial cone extending along the western side of the Mississippi Valley for a distance of over 200 miles. The upper part of the cone has been largely removed by erosion or buried by Holocene meander belts; however, much of the lower part remains and forms a low ridge called Macon Ridge (Fig. i). 
The extent and topographic expression of Macon Ridge at the latitude at which the Ouachita River enters the Mississippi Valley are shown in Figure 7. Four levels, designated A through $D$, are recognized; the easternmost level (level A) is the highest and oldest and the westernmost level (level D) is the lowest and youngest. Preserved braided drainage patterns indicate that the levels are terraces resulting from progressive westward shifting of the ancestral Arkansas River while it was slowly degrading its floodplain. 'Radiocarbon dates reported by Saucier (1968) from near the surface of Macon Ridge 8 miles southeast of Winnsboro, La. (Fig. 7) indicate the deposits of level $\mathrm{C}$ to be about 30,000 years old. Inferred rates of sedimentation and stream migration and relative stratigraphic positions suggest that the deposits. in level A are not more than a few thousand years older than this. On the basis of topographic position and the radiocarbon dates, level A of Macon Ridge is considered to represent the greatest extent of aggradation in the Mississippi Valley during the Farmdalian Substage.

Alluviation in the Ouachita Valley (Fig. 6c) can be assumed to have been in equilibrium with alluviation (Mississippi River valley train development and Arkansas River cone development) in the Mississippi alluvial valley. during much of the period of waning Early Wisconsin glaciation. However, with the attainment of full development of Macon Ridge during the Farmdalian Substage, disequilibrium apparently resulted. It is felt that the rate of deposition of the last few tens of feet of sediment in Macon Ridge culminating in level $A$ was so rapid that aggradation of the Ouachita floodplain could not keep pace. The result of this was the creation of what was ef-. fectively a dam across the lower end of the Ouachita Valley in the vicinity of Monroe and the consequent formation of first a swampy basin similar to 

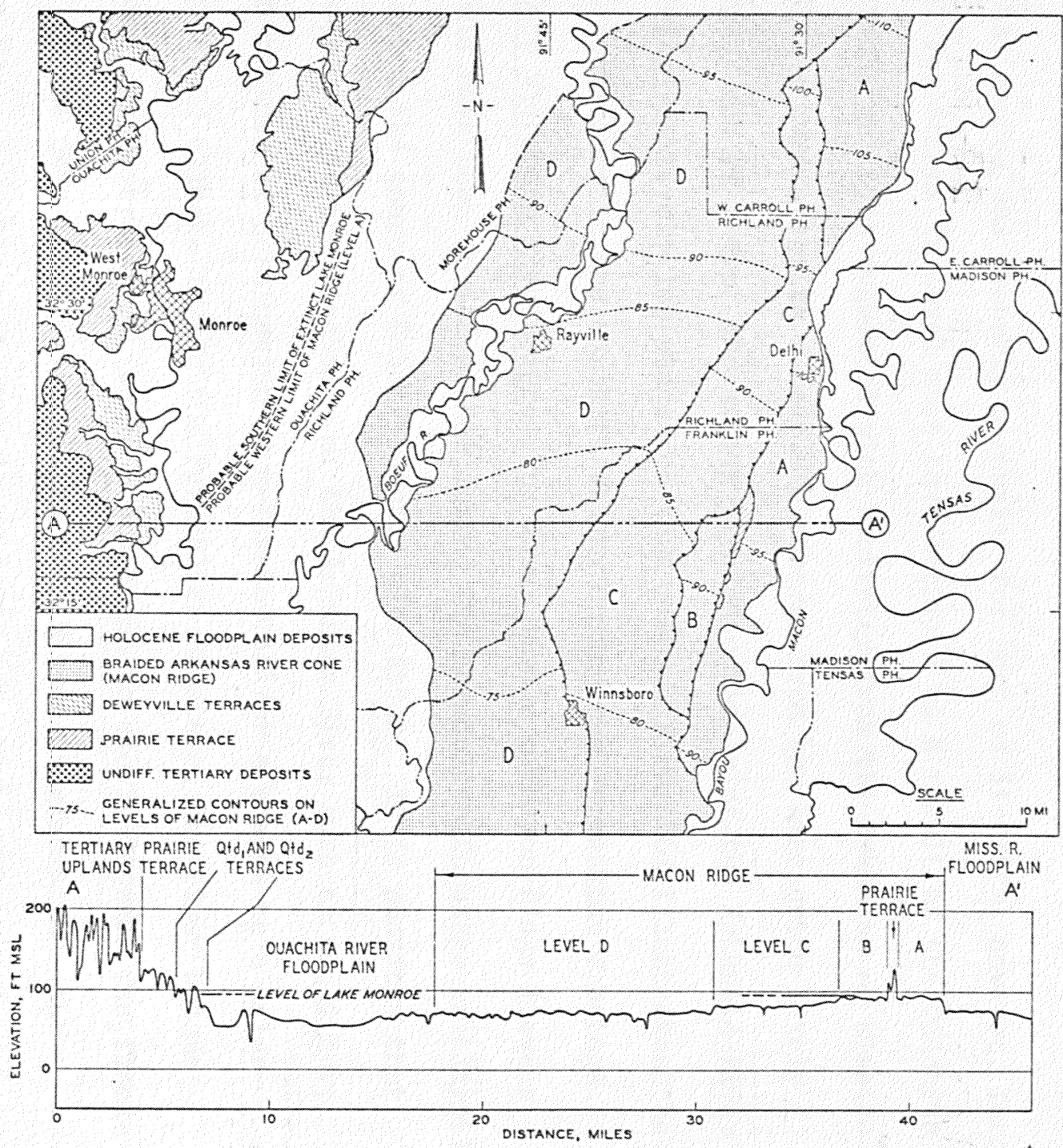

Figure 7. Extent and configuration of the Farmalian Substage Arkansas River cone (Macon Ridge) as related to the formation of Lake Monroe. 
the Grand Marais and finally Lake Monroe. Profile A-A', Figure 7, illustrates that the highest points on level A of Macon Ridge (i.e. the closest approximation to the original surface) are within 2 or 3 ft of the reconstructed mean maximum level of Lake Monroe, an elevation of about $97 \mathrm{ft}$ msl. There is no reason to doubt that level A of Macon Ridge once extended as far west as the limit indicated in Figure 7 .

Lake Monroe was probably perennial for much of its life; however, large seasonal variations in level must have occurred as a result of the Ouachita River discharge being augmented with backwater from the Arkansas or Mississippi Rivers during spring floods. Discharge from the lake quite likely occurred by way of one of the active braided channels of the Arkansas River only during relatively low stages on that river. Figure $6 d$ illustrates the assumed conditions in the Ouachita Valley during the Farmalian Substage. Late Wisconsin glaciation. The lower levels of Macon Ridge (levels B-D) could have been formed either during the Farmdalian Substage or slightly... later during the onset of Late Wisconsin glaciation. It is possible that with a decrease in the discharge of the Arkansas River such as could have. occurred because of termination of meltwater and/or a change to a drier (interglacial) climate during the Farmdalian substage, the river became more competent to transport its load and began to slowly degrade its floodplain. On the other hand, with waxing Iate. Wisconsin glaciation; the Arkansas River as well as the Mississippi River would have begun steepening their gradients and degrading their floodplains in response to falling sea level. If the Farmalian Substage was as brief as suggested by Curray (1965) (Fig. 5b), it is likely that conditions of climate and glaciation that would permit a significant decrease in discharge did not develop; 
hence the latter interpretation is favored. In either case, the results would have been the same. The alluvial-ridge barrier responsible for creating and maintaining Lake Monroe for possibly as long as several. .thousand years was destroyed or breached sufficiently to allow the lake to drain.

With continued waxing glaciation and a resultant major eustatic lowering of sea level between 20,000 and 25,000 years ago (Fig. 5b), the Arkansas River eventually became significantly entrenched. The axis of the entrenched valley is known to be between the western edge of Macon Ridge (Fig. 7) and the Tertiary uplands or older terrace remnants (e.g., the Bastrop Hills). In the Ouachita Valley, the ancestral Ouachita River unquestionably was affected by the falling base level and also was forced to degrade its floodplain. However, during this interval, the river alsowas forced to accommodate itself to a significantly greater discharge. The resulting adaptation to the change in hydraulic regime is manifested by the Qtd 3 terrace. As the floodplain represented by this terrace developed, large areas of the lacustrine plain that resulted from the draining of Lake Monroe were destroyed by lateral migration of the river. The relationship that developed between the Qtd 3 terrace and the lacustrine plain (atd 2 terrace) is diagrammatically illustrated in Figure 6e. The downvalley terrace profiles included in Figure 2 indicate that net degradation by the river during waxing late Wisconsin glaciation took place along the entire stretch of river included in this study. Woodfordian Substage. The projected downvalley slope of the Qtd 3 ter-. race suggests that the Arkansas River at that time had entrenched itse If to about the level of the present floodplain (i.e an elevation of about. 
$65 \mathrm{ft} \mathrm{ms}$ ) some 10 to 15 miles south of Monroe where the Ouachita River probably became tributary to the Arkansas River. The maximum depth of entrenchment or degradation attained later at or shortly after the maximum extent of the Late Wisconsin glaciation (the Woodfordian Substage) is not known with certainty; however, if the thickness of the Holocene topstratum (backswamp and natural levee deposits) in this area is subtracted from the floodplain elevation, a probable minimum elevation of $20 \mathrm{ft} \mathrm{ms} \mathrm{I}$ is indicated for the deepest entrenchment.

With the Arkansas River near Monroe entrenched to an elevation of 20 ft msl or lower, the Ouachita River was forced to accommodate and apparently did so by further degrading its floodplain. The indicated minimum degradation of the Ouachita River floodplain compatible with changes in the Arkansas River is a level about 15 ft below the present floodplain (excluding the effects of the Bayou Bartholomew course).

It has not been possible to determine the precise character of the Ouachita River at the time of maximum entrenchment. The floodplain width : necessarily was equal to or less than the present floodplain width, suggesting that the river during the Woodfordian Substage might have been somewhat smaller in size (i.e. a lesser discharge) than it was when the atd 3 terrace was formed. Scallops in the atd 3 terrace along the contact with the present floodplain but not attributable to observable Holocene floodplain channels suggest that the river was basically a meandering stream at or shortly after the time of maximum entrenchment. 
The Recent. ${ }^{1}$ When the Late Wisconsin glaciation began waning and sea level began rising, the process of entrenchment was halted and floodplain aggradation became dominant. Evidence indicates that the Mississippi and Ohio River valley trains developed east of Crowleys Ridge and trended through the Yazoo Basin into Louisiana east of Macon Ridge (Fig. 1). The Arkansas River began building a cone from the point where the river flows out of the Ozark Mountains province near Little Rock. Possibly because of the development of this cone and the rapid filling of the upper part of the entrenchment, the Arkansas River in a rather early stage of waning glaciation diverted from the entrenched valley west of Macon Ridge to a more easterly course that trended more directly toward the Mississippi River. Thus deprived of its primary source of alluvium, the lower part of the entrenchment, including the area adjacent to the Ouachita valley,-aggraded slowly through the accumulation of mostly fine-grained sediments introduced by minor streams and derived from backwater flooding by the Mississippi River. Presumably the Ouachita River was capable of

I. It has been rather common practice in the central Gulf. Coast area to define the Recent as being the period of time following the last major low stand of sea level (Russell, 1940) rather than as being the time following the cessation of continental glaciation. According to the former definition, most Recent deltaic and alluvial valley deposits would be separable from Pleistocene deposits by an erosional unconformity, whereas, according to the latter definition; no persistent time-stratigraphic division would be present. Russell's definition is considered convenient for use in this paper at this point. 
aggrading its floodplain at a corresponding rate also through the accumulation of primarily fine-grained materials:

The Arkansas River ceased building a cone and became a tightly meandering stream carrying a much smaller sediment load perhaps by as early as 10,000 years ago. During the following several thousand years, meander belts were formed extending for more than 200 miles southeast and south of Iittle Rock into Louisiana along both sides of Macon Ridge. Bayou Macon and Boeuf River now each occupy abandoned Arkansas River meander belts in the latitude of - Monroe (Fig. 7). The meander belt occupied by Bayou Macon is the older of the two; however, archaeological evidence (Webb, 1968) indicates both were well developed and possibly even abandoned by the Arkansas River by about 3000 to 3500 years ago. It was about this time or slightly later that the Arkansas River developed the Bayou Bartholomew course by diverting through the gap in the Prairie terrace formation at the north end of the Bastrop Hills and into the Ouachita River floodplain near Sterlington. Abandonment of the Bayou Bartholomew course by the Arkansas River probably took place about 1000 to 1500 years ago.

Figure $6 f$ diagrammatically illustrates conditions in the Ouachita valley as they exist today and, in effect, as they have been during the past 1000 years or more. During this time, the Ouachita River floodplain has probably aggraded only a few feet through the accumulation of backswamp and natural levee deposits. Course changes and formations of cutoffs have probably been minor and infrequent.

\section{DISCUSSION}

Extinct Lakes

Numerous swampy depressions and occasionally small lakes are present 
in the Mississippi alluvial valley and the floodplains of its major tributaries as a result of more rapid alluviation by one stream serving to block or dam the mouth of a smaller stream; a process sometimes referred to as alluvial drowning. Typically, the drowning is caused by the growth of natural levees along a newly developing meander belt of a major stream located a short distance from (i.e. several miles or less) and trending roughly parallel to a terrace or other upland. Small streams discharging from the upland are ponded in their lower reaches because of an inability to aggrade their floodplains to the level of the natural levees.

Lake Monroe is unusual because of its large size and the fact that it is the first extinct lake to be recognized as having been created in the Mississippi alluvial valley area as a result of the development of alluvial cones or valley trains (braided stream deposition). Subsequent to its discovery, an examination of topographic quadrangles and aerial photographs revealed the probable former existence of similar but smaller extinct lakes on the Hatchie, Obion, and Forked Deer Rivers in western Tennessee and pos: sibly also on the Big Black River in west-central Mississippi. Each of these streams has in its valley a low terrace that has a very low or nil downvalley $\checkmark$ slope in proximity to the Mississippi alluvial valley. The projected slopes of these terraces indicate that the streams were graded to the approximate highest elevations of the Farmdalian Substage valley trains of the Ohio and Mississippi Rivers. Sufficient work has not been done to determine if shoreline features are present along the sides of the valleys of these smaller. streams. The situation on the Hatchie River is particularly similar to that on the Ouachita River in that there is not only a terrace which appears to be a correlative of the $Q t d_{1}-Q t d 2$ levels but there are also fluvial 
features analogous to those of the atd $_{3}$ level in the same position relative to the older level.

Other streams in the Mississippi alluvial valley area whose physical settings and locations relative to the alluvial valley would have been conducive to the formation of lakes during Farmdalian Substage valley train development would include the Coldwater, Tallahatchie, Yalobusha, and Yokona Rivers of northwestern Mississippi. Each of these rivers has at least one terrace; however, no attempt has been made to analyze terrace slopes or morphology.

An extinct lake quite analogous to Lake Monroe is known to have existed along the lower Ohio, Tennessee, and Clark Rivers in Kentucky and Illinois for 40 miles above Metropolis, IIl. (Finch and others, 1946). Primary evidence for this lake, named Lake Paducah, is in the form of relict bay-mouth bars and beaches highly similar to those around Lake Monroe. The age of Iake Paducah is indicated by radiocarbon dates as being about 21,000 years (Olive, 1966) and rapid alluviation in the Ohio-valley is a possible explanation for its formation.

Thus far, there is no evidence that lakes formed on eastern tributaries to the Mississippi Valley during the early Recent when valley train developed because of waning Late Wisconsin glaciation. It is possible that they did develop and that their shorelines either coincide with older similar features or are now buried beneath Holocene floodplain deposits.

Age and Origin of Deweyville Terraces

Radiocarbon dates on materials from the Deweyville terraces along several Gulf Coast streams vary from 13,000 to 30,000 years before present. 
Along the Atlantic Coast, radiocarbon dates indicate formation of equivalents of this terrace between 17,000 and 36,000 years before present (Gagliano and Thom, 1967). In spite of the considerable time span indicated by the dates, there has been a strong tendency to want to correlate the Deweyville with events that occurred during a period of only a few thousand years at the end of the time span such as rising sea level (Bernard and LeBlanc, 1965) or at... the beginning of the time span, i.e. the Farmdalian Substage (Gagliano and Thom, 1967; Saucier, .1968).

The authors feel that this tendency has been motivated in large measure by exposure to popular Fiskian concepts in which fluvial terrace formation in the Lower Mississippi Valley area is assumed to have occurred only during interglacial stages or advanced stages of waning glactiation (Fisk, 1944). Terrace stratigraphy along the Ouachita River strongly indicates that terrace formation took place during late interglacial times and continued through much of a period of waxing glaciation. The Qtd 3 terrace, more typical of the Deweyville terraces as they occur on other Gulf and Atlantic Coast streams, is undoubtedly a glacial rather than an interglacial stage terrace.

Evidence indicates that the Qtd ${ }_{1}$ and. Qtd 2 terraces can be correlated with the culmination of alluviation in the Mississippi alluvial valleyduring the Farmdalian Substage some 28,000 to 30,000 years ago. The atd 3 terrace formed at some later time but before the maximum extent of Late Wiscons in glaciation (Woodfordian Substage) about 18,000 years ago. Topo-. graphic relationships and terrace slopes indicate that the $\mathrm{td}_{3}$ terrace was formed while the river was adjusting to a falling base level brought 
about by entrenchment of streams in the Mississippi alluvial valley.

The Deweyville terraces along the Ouachita River differ from those of other streams along the Gulf and Atlantic Coasts in regard to certaincausal factors, but not in regard to their effects. Alluviation or aggradation followed by entrenchment or degradation in the Mississippi alIuvial valley was essential to the formation of terraces in the Ouachita Valley, whereas along the other streams, a coincident high sea level stand followed 'by' falling sea level apparently had similar effects. The fact ${ }^{-}$ that Iake Monroe formed in the Ouachita Valley and the Qtd 1 and Qtd 2 terraces are basically lacustrine in origin in the lower part of the valley is not considered significant in this regard. Its formation is considered as simply a local manifestation of an otherwise regional aggradational trend. It was largely for this reason that the authors designated the atd $d_{1}$ and Qtd 2 terraces as Deweyville terraces rather than introduce new names for them.

Deweyville Paleoclimatology and Paleohydrology

Although evidence from the Ouachita Valley could be interpreted as indicating that degradation of the valley during Deweyville times was a direct response to entrenchment in the Mississippi alluvial valley, doubt has been expressed recently that there was sufficient time-during the Wisconsinan Stage for streams to have adjusted their gradients to falling base levels (either entrenchments or sea level) for any appreciable distance above their mouths. Parallelism between gradients of terrace surfaces for long distances downvalley with sudden steepening of gradients near the coast, such as illustrated by Thom (1967) for streams in South Carolina, is 
one form of evidence that has been cited by proponents of this idea.

If the correlation of the $\mathrm{Qtd}_{3}$ terrace with waxing Late Wisconsin glaciation is correct, this would mean that the terrace was formed during a period of pluvial climate. This is certainly indicated by the large relict meanders on the terrace. Schumm (1965) indicates that although opinions vary considerably, the consensus is that an increase in annual precipitation of $10 \mathrm{in}$. and a decrease in mean annual temperature of $10^{\circ} \mathrm{F}$ could have occurred in the southeastern United States during the last glaciation. Using these values, Schumm (1965, p. 791) has concluded from an assessment of the effect of a cooler and wetter climate on runoff, sediment yield, and sediment concentration, that stream incision or degradation would have resulted. He calls attention to an example of stream incision during late interglacial to mid glacial time followed by stream deposition during full glacial to early interglacial time along the Red River in Texas observed by Frye and Leonard (1963).

Thus, it appears reasonable that the Deweyville terrace of the Ouachita, as well as of all other Gulf and Atlantic Coastal Plain streams; may have originated as a result of two different processes (i.e., eustatic sea level. variations and climatic change) operating simultaneously to produce similar effects.

Empirical relationships between certain stream geometry parameters and stream discharge developed by Carlston (1965) and Schumm (1969) can be applied to the situation in the Ouachita River area to derive a quantitative estimate of the paleodischarge of the $\mathrm{atd}_{3}$-stage stream. It was decided. that the relative validity of the various equations could be tested by applying them first to measurable parameters of the present river and then comparing the results with known discharge values. 
As indicated by Schumm (1969), geometry parameters such as channel width, depth, gradient, and wavelength appear to be determined by both discharge and type of sediment load moved through the channel. Data are not available in the case of the Ouachita River area to indicate the nature of the sediment load in either the present river channel or the

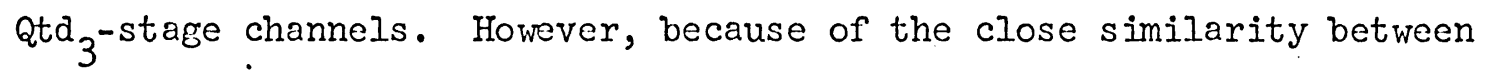
the Iithology of the Qtd 3 terrace and that of the Holocene alluvial sequence, it has been assumed for comparative purposes that the sediment load of the river was the same during the Qtd 3 stage as it has been during the Holocene. It is further assumed, therefore, that observable variations in geometry parameters are entirely a result of different discharges. As illustrated in Figure 2, there is no significant difference between the Qtd $_{3}$ terrace gradient and the Holocene floodplain gradient. Although it is not possible to reconstruct the sinuosity of the Qtd $3^{- \text {stage }}$ river, it has been assumed that the value of this parameter was essentially the same as that of the present river. Thus, meander wavelength, channel width, and channel depth emerge as the only variable parameters for which empirical equations are available that can be measured for both the Qtd $_{3}$-stage and the Holocene channels.

Measurements of the geometry parameters of the present river channel and Holocene abandoned channels (Table 1) were made between Camden and the mouth of the Saline River. This areal restriction was necessary to avoid the complicating factor of added discharge from a major tributary and also to avoid an area in which the morphology of the present river is known to have been strongly influenced by the Arkansas, River. To permit 
Table 1. Holocene and Deweyville (Qtd 3 stage) Stream Geometry Measurements

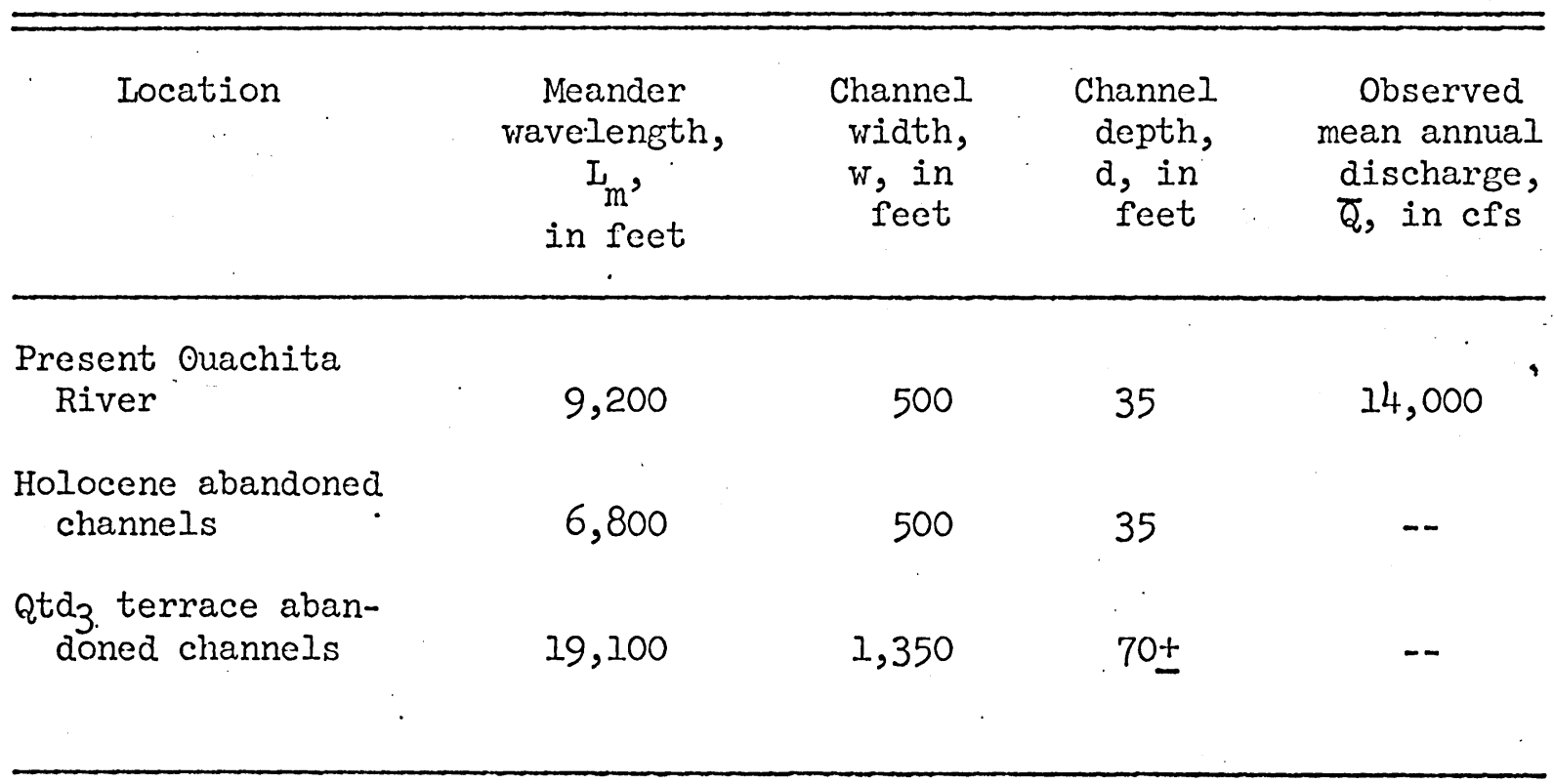


a valid correlation, all Qtd 3 terrace stream channel measurements were restricted to the same area.

The meander wavelength $\left(I_{m}\right)$ value for the present river was obtained by calculating the average meander radius and multiplying by four. This procedure was determined through trial and error to be the only practical method, and it was employed only along those stretches of river that appeared to be relatively free from external complicating controls such as impingement of channel against valley wall. The channel width (w) value is an average of a number of measurements made from aerial photographs and represents the bankfull width. The channel depth (d) value is also an average derived from hydrographic surveys and represents the interval from the bankfull elevation to the average maximum channel elevation. A cursory examination of maps and aerial photographs revealed a distinctive difference in size between the radii of active river channel meanders and those of Holocene abandoned channels. In view of the fact that all Qtd ${ }_{3}$ terrace channel parameter measurements necessarily could be made only from abandoned channels, values for $I_{m}, w$, and $d$ were obtained for the Holocene abandoned channels to permit a more valid correlation. As indicated in Table 1 , the abandoned channels have a significantly smaller $I_{m}$ value than active channel meanders but are identical in regard to values for $w$ and $d$.

Values for $I_{m}$ and $w$ for the $a_{3} d_{3}$ terrace abandoned channels were obtained from maps and aerial photographs. To obtain a sufficient number of individual measurements, it was necessary to use all discernible channels. Therefore, it has been necessary to make the assumption that all 
channels, regardless of size variation, represent a static discharge condition and do not represent a transition from or to a lesser discharge. The $d$ value for the $\mathrm{Qtd}_{3}$ terrace abandoned channels is considered to be the least reliable value obtained. Since no precise depths are known, the value could be derived only by inference from such observations as the thickness of the terrace alluvial sequence.

The mean annual discharge (Q) value indicated in Table 1 for the present river was obtained by subtracting the discharges of the Saline River, Bayou Bartholomew, and Bayou d'Arbonne from the known discharge (27-year record) of the Ouachita River at Monroe. These streams are the only tributaries of consequence in the area, therefore the value for $\bar{Q}$ should be correct to within less than $1000 \mathrm{cfs}$.

Discharges calculated from equations 12 and 22 of Carlston (1965, p. 875 and 879) and equations 4 and 10 of Schumm (1969, p. 257-258) are included in Table 2. In both equations of Schumm, a value, $M$, is included which represents the percent of silt and clay (sediments finer than $0.074 \mathrm{~mm}$ ) in the sediments forming the perimeter of the channel. No quantitative data are available on the nature of the sediment load in: the Ouachita River area. To overcome this problem, the width/depth ratio (w/d) was substituted for M. According to Schumm (personal communication), the channel shape or w/d closely reflects the type of sediment load. The large variation in values for $\bar{Q}$ show in Table 2 is not unexpected.considering the nature of the equations and the possible major inaccuracies in geometry parameter measurements used in them. While neither the equations of Carlston nor those of Schumm could produce values for the 
Table 2. Holocene and Deweyville (Qtd3 stage) Stream Discharges Calculated from Empirical Equations

Location

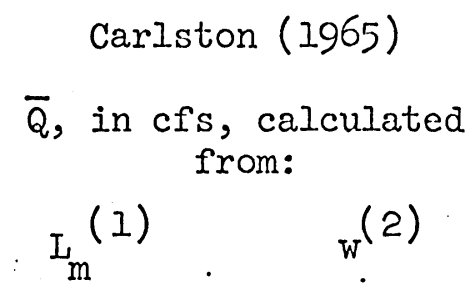

Schumm (1969)

$\bar{Q}$, in cfs, calculated from:

$L_{m}(1) \quad \mathrm{w}^{(2)} \quad \mathrm{L}_{\mathrm{m}}(3)$

$\mathrm{w}^{(4)}$

Present Ouachita

River

16,300

10,700

34,200

12,500

Holocene abandoned

channels

8,500

10,700

14,000

12,500

$\mathrm{Qtd}_{3}$ terrace aban-

doned channels

80,000

92,900

564,700

229,200

(I) $I_{m}=106.1 \bar{Q}^{0.46}$

(3) $I_{m}=1890 \frac{\bar{Q}^{0.34}}{0.74}$

$\left(\frac{\mathrm{w}}{\mathrm{d}}\right)$

(2) $w=7 \bar{Q}^{-0.46}$

(4) $\mathrm{w}=37 \frac{\overline{\mathrm{Q}}^{-0.38}}{0.39}$

$\left(\frac{\mathrm{w}}{\mathrm{d}}\right)$ 
present river closely duplicating the know discharge, those of Carlston show considerably less variation. In the authors' opinion, the values for $\bar{Q}$ for the Qtd $_{3}$ terrace abandoned channels derived from Carlston's equations are probably more nearly correct. The inability to derive an accurate value for $d$ which is an integral part of both of Schumm's equations (but not Carlston's) is one factor to be considered as is the fact that Schum's equations, unlike those of Carlston, result from an analysis of rivers that are, for the most part, located in subhumid and semiarid regions (Schumm, 1969, p. 259). The validity of Schumm's equations is further negated by the conspicuously anomalous value for $\bar{Q}$ of 564,700 cfs as determined from $I_{m}$ for the Qtd 3 terrace channels. This value is almost identical-with the value for $\bar{Q}$ for the obviously much larger Mississippi River at Vicksburg, Miss.

According to Dury (1965) who made an intensive effort to estimate paleodischarge by using the relationship that exists between meander characteristics of modern rivers and their discharge, a value for $\bar{Q}$ of 5 to 10 times greater than the present value was found to be common for a large number of streams representing a wide geographic coverage. A similar ratio of paleodischarge to present discharge was observed by Schumm (1968) in a study of an Australian river system somewhat analogous to the Ouachita River. Both values for $\bar{Q}$ calculated by using CarIston's equations fall within this range, whereas those calculated using Schumm's equations greatly exceed the range.

Assuming a value for $\bar{Q}$ of 80,000 to $90,000 \mathrm{cfs}$ for the Qtd $3^{\text {-stage }}$ stream to be correct, the paleoclimatic implications are significant. Under 
present climatic conditions with a mean annual precipitation of about 52 in. and a mean annual temperature of about $63^{\circ} \mathrm{F}$, the mean annual runoff from the Ouachita drainage basin above the mouth of the Saline River is approximately 18 in: With a value for $\bar{Q}$ of 80,000 to $90,000 \mathrm{cfs}$, the mean annual runoff would be approximately 100 to 115 in. Using curves presented by Schumm (1965, p. 784), it can be seen that regardless of what the mean annual temperature may have been, a runoff of this magnitude probably required:' a mean annual precipitation of at least $100 \mathrm{in.}$ This value is considerably more than has been postulated by Schumm and others for this area during a pluvial climate. Although one could argue that even Carlston's equations yield anomalously high paleodischarge values and thereby exaggerate inferred munoffs and precipitation, it must be remembered that the Deweyville terraces on other Gulf and Atlantic Coastal Plain streams have relict channels that are even larger in comparison to the present channels than they are along the Ouachita River. 
Allen, J. R. I., 1965, A review of the origin and characteristics of Recent alluvial sediments: Sedimentology, v. 5, no. 2, p. 9l-19l. Bernard, H. A., 1950, Quaternary geology of southeast Texas: Ph.D. dissert., Iouisiana State Univ., Baton Rouge, La., 165 p.

Bernard, H. A., and IeBlanc, R. J., 1965, Résumé of the Quaternary geology, $\therefore$ of the northwestern Gulf of Mexico, in Wright, H. E., Jr., and Frey, D. G., Editors, The Quaternary of the United States: Princeton Univ. Press, p. 137-185.

Carl.ston, C. W., 1965, The relation of free meander geometry to stream discharge and its geomorphic implications: Am. Jour. Sci., v. 263, p. $864-885$.

Curray, J. R., 1965, Late Quaternary history, continental shelves of the .United States, in Wright, H. E., Jr., and Frey, D. G., Editors, The Quaternary of the United States: Princeton Univ. Press, p. 723-735. Doering; J. A., 1956, Review of Quaternary surface formations of_Gulf Coast region: Am. Assoc. Petroleum Geologists Bull., v. 40, no. 8, p. 1816-1862.

Durham, C. 0., Jr., Moore, C. H., Jr., and Parsons, B., 1967, An agnostic view of the terraces: Natchez to New Orleans: Geol. Soc. America. Field Trip Guidebook, New Orleans, 1967, p. El-E22.

Dury, G. H., 1965, Theoretical implications of underfit streams: U. S. Geol. Survey Prof. Paper 452-c, 43 p.

Finch, W. I., Olive, W. W., and Wolfe, E. W., 1964, Ancient lake in western 
Kentucky and southern Illinois, in Geological Survey Research; 1964:

U. S. Geol. Survey Prof. Paper 501-C, p. C130-C133.

Fisk, H. N., 1939, Depositional terrace slopes in Louisiana: Jour. Geomorphology, v. 2, no. 2, p. 181-200.

1944, Geological investigation of the alluvial valley of the lower

Mississippi River: Vicksburg, Miss., U. S. Army Corps Engineers, Miss. River Comm., 78 p.

Fisk, H. N., and McFarlan, E., Jr., 1955, Late Quaternary deltaic deposits of the Mississippi River: Geol. Soc. America Special Paper 62, p. 279-302.

Fleetwood, A. R.; 1969, Geological investigation of the Ouachita River area, Lower Mississippi Valley: Vicksburg, Miss., U. S. Army Engr. Waterways Experiment Sta., Tech. Rept. S-69-2, 24 p:

Frye, J."C. , and Leonard, A. B., 1963, Pleistocene geology of Red River basin in Texas: Univ. Texas Bur. Econ. Geology Rept. Invest. No. $49,48 \mathrm{p}$.

Gagliano, S. M., and Thom, B. G., 1967, Deweyville terrace, Gulf and Atlantic coasts: Louisiana State Univ.," Coastal Studies Bull. I, p. $23-41$.

Hoyt, J. H., Weimer, R. J., and Henry, V. J., Jr., 1968, Age of Late-. Pleistocene shoreline deposits, coastal Georgia, p. 381-393 in Morrison, R. B., and.Wright, H. E., Jr., Editors, Means of correlation of Quaternary successions: Proc. Internat. Assoc. for Quaternary Research, VII Internat. Cong., v. 8, 631 p.

Leighton, M. M., and Willman, H. B., 1949, Late Cenozoic geology of Mississippi valley: Itinerary of Field Conf., June 12-25, 1949. 
Olive, W. W., 1966, Lake Paducah, of late Pleistocene age, in vestern

Kentucky and southern Illinois, in Geological Survey Research, 1966:

U. S. Geol. Survey Prof. Paper 550-D, p. D87-D88.

Pearson, F. J., Jr., Davis, E. M., and Tamers, M. A., 1966, University of

Texas radiocarbon dates IV: Radiocarbon, v. 8, p. 453-466.

Russell, R. J., 1940, Quaternary history of Louisiana: Geol. Soc.

America Bull., v. 51, p. 1199-123l.

Saucier, R. T., 1968, A new chronology for braided stream surface formation in the Lower Mississippi Valley: Southeastern Geology, v. 9, no. 2, p. $65-76$.

Schnable, J. E., 1966, The evolution and development of part of the northwest Florida coast: Florida State Univ., The Sedimentological Research Lab., Cont. No. 12, $231 \mathrm{p}$.

Schumm, S. A., 1965, Quaternary paleohydrology, in Wright, H. E., Jr., and Frey, D. G., Editors, The Quaternary of the United States:

Princeton Univ. Press, p. 783-794.

1968, River adjustment to altered hydrologic regimen-Murrumbidgee

River and paleochannels, Australia: U. S. Geol. Survey Prof. Paper $598,65 \mathrm{p}$.

1969, River metamorphosis: Jour. Hydr. Div., Am. Soc. Civil Engr. Proc., v. 25, no. HYl, p. 255-273.

Thom, B. G., 1967, Coastal and fluvial landforms; Horry and Marion Counties, South Carolina: Louisiana State Univ., Coastal Studies Inst. Tech. Rept. 44, 75 p.

Trowbridge, A. C., 1954, Mississippi River and Gulf Coast terraces and 
sediments as related to Pleistocene history-a problem: Geol. Soc. America Bull., v. 65, no. 8, p. 793-812.

Veatch, A. C., 1906, Geology and underground water resources of northern Louisiana and southern Arkansas: U. S. Geol. Survey Prof. Paper 46, $422 \mathrm{p}$.

Webb, C. H., 1968, The extent and content of Poverty Point culture: American Antiquity, v. 33, no. 3, p. 297-321. 


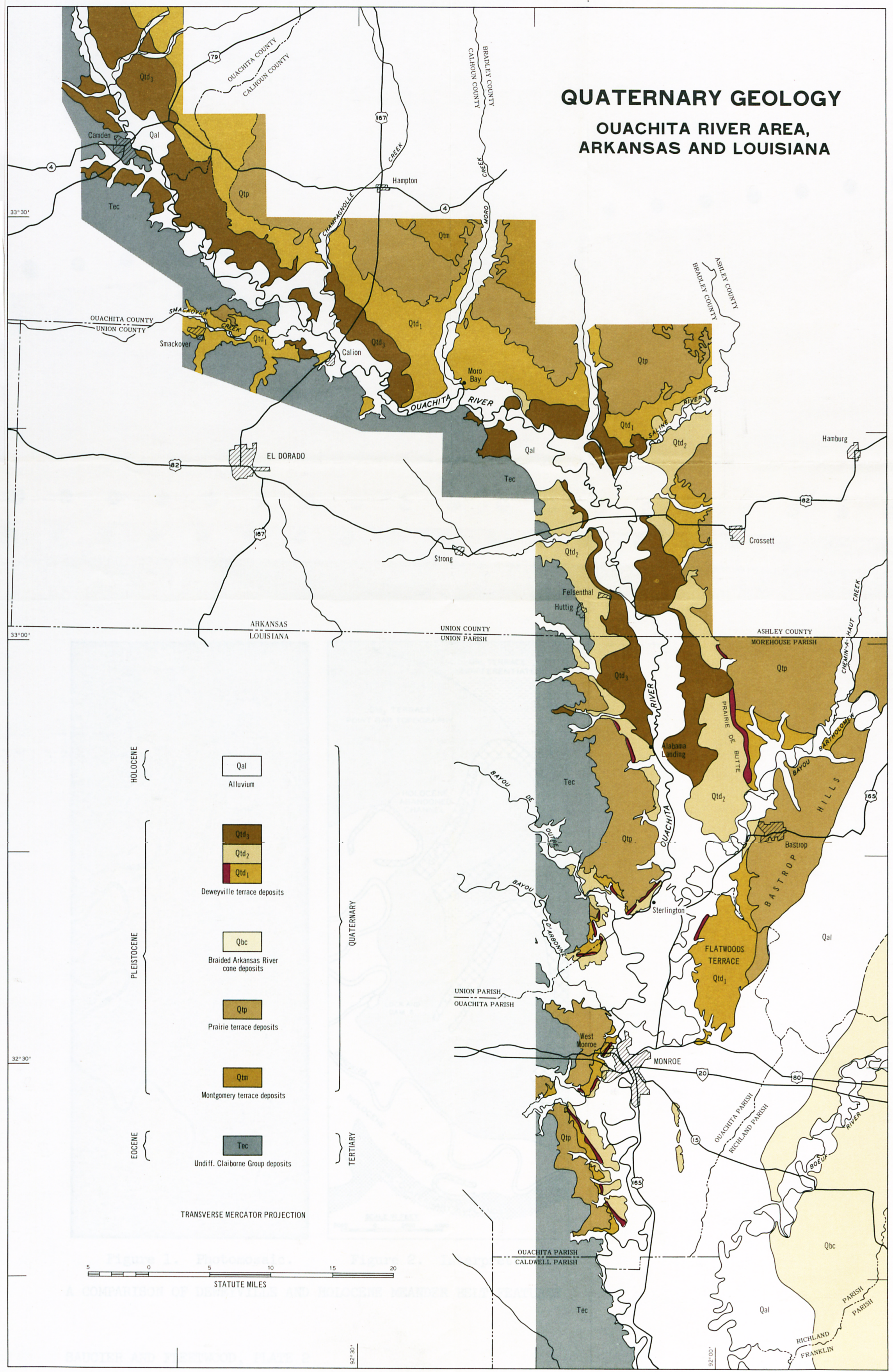




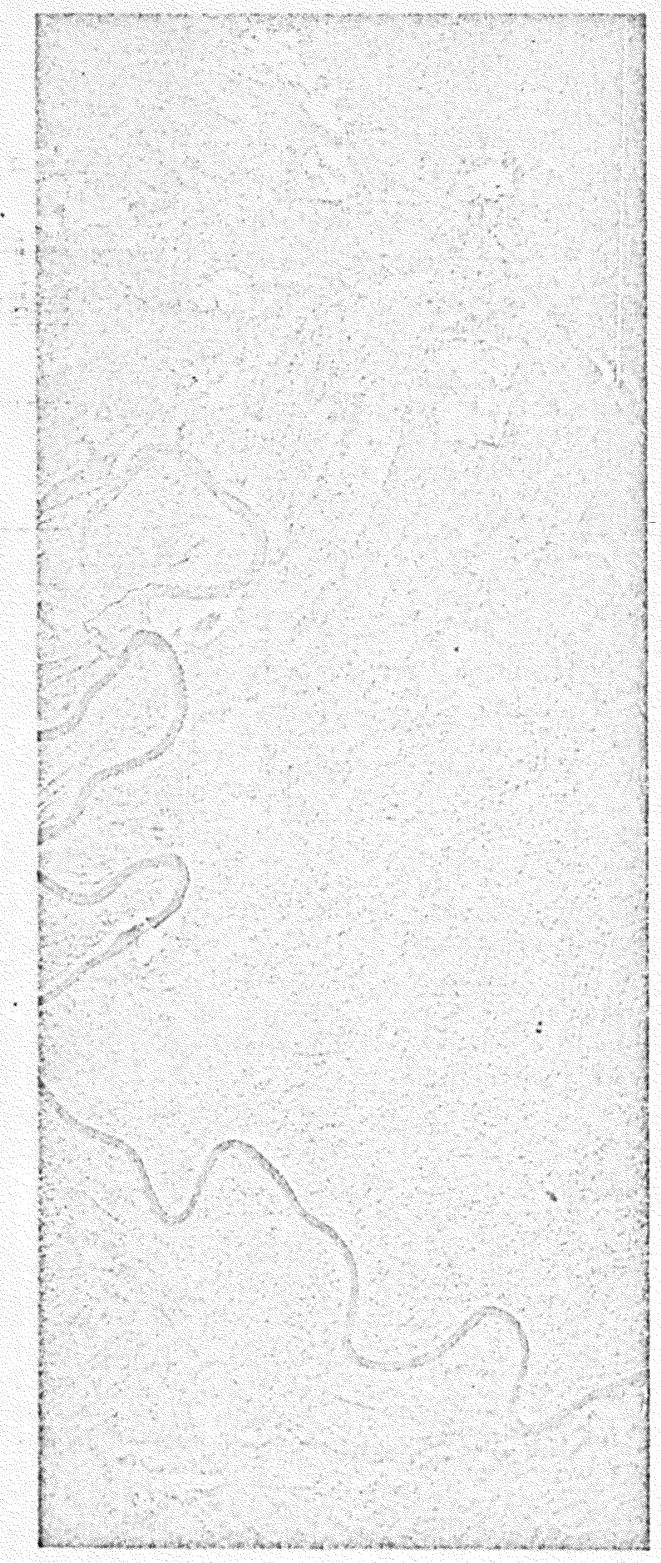

Figure 1. Photomosaic.

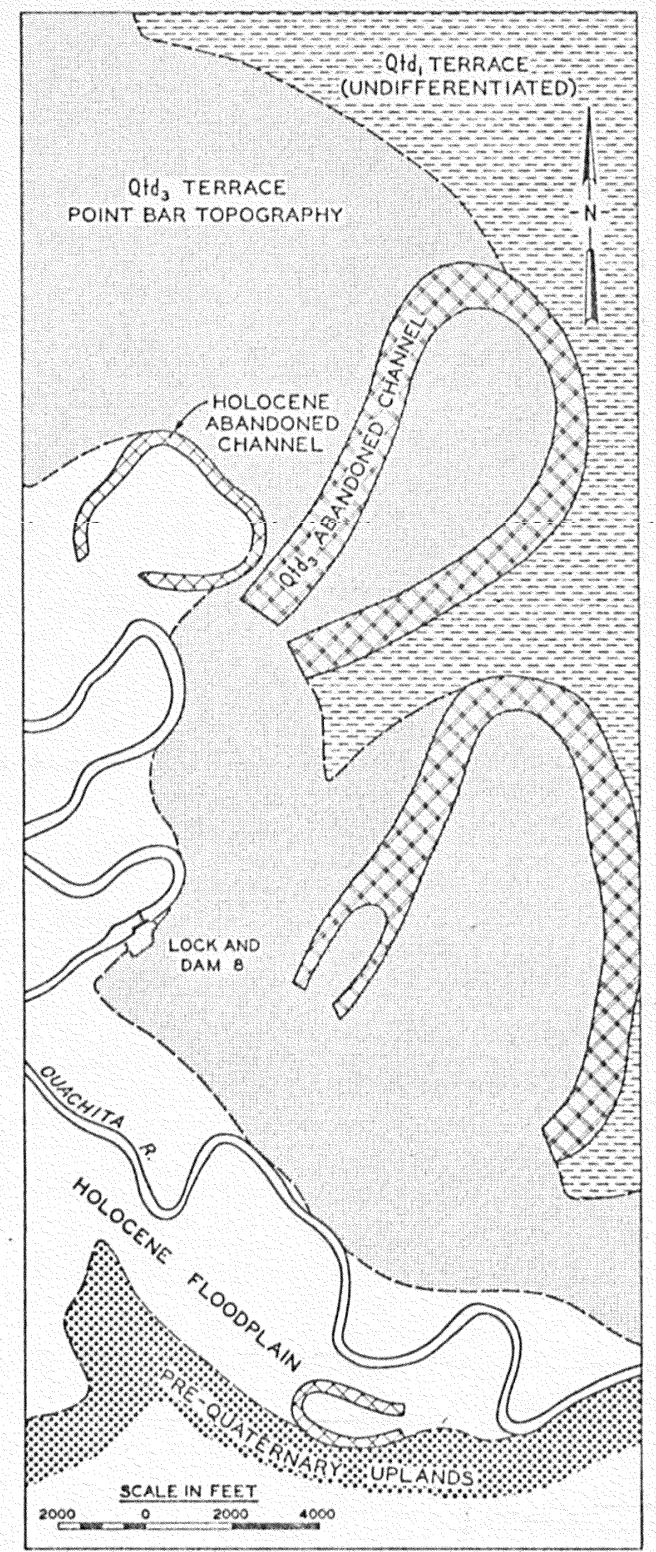

Figure 2. Interpretation.

A COMPARISON OF DEWEYVILIE AND HOLOCENE MEANDER BELT FEATURES

SAUCIER AND FIEETWOOD, PLATE 2 